\title{
Kategorizácia škôd spôsobených trestným činom (II. čast')
}

\section{Categorization of Damages Caused by a Crime (Part. II)}

\author{
Jozef Čentéśs* $^{* *}$ Andrej Beleš ${ }^{* * *}$, Jana Čipková ${ }^{* * * *}$
}

\begin{abstract}
Abstrakt
Nasledujúci príspevok predstavuje drubé pokračovanie stúdie pojednávajúcej o kategorizácii škôd spôsobených trestným činom. Autori prenášajú svoju pozornost'k širšie uplatnitelným úvahám a námetom de lege ferenda, majücich potenciál byt'prinosom nielen slovenskej, ale i českej trestnej legislativy. Ich rozboru podlieba novela Trestnébo zákonnika č. 333/2020 Sb., ktorá ustanovila zdvojnásobenie súm urúujúcich jednotlivé branice výšk škôd, ako i odpoved' na otázku, ¿̌ je v podmienkach Slovenskej alebo Českej republiky mo:̌né prehodnotit' väzbu škody na jeden z flexibilných ekonomických inštitútov. Záverom sa zamýslajú nad potrebou intertemporálneho ustanovenia, podl'a ktorébo sa tresty uložené pred účinnost’ou novej právnej úpravy nevykonajú, prípadne pomerne skrátia.
\end{abstract}

\section{Klíčová slova}

Škoda; kategoriqácia škôd; výška škody; trestná zodpovednost.

\section{Abstract}

The following lines represent the second episode of the research related to the categorization of damages caused by a crime. The authors transfer their attention to wider considerations and suggestions de lege ferenda that may have the potential to be beneficial not only for Slovak but also for Czech criminal legislation. The subject of their analysis consists of the analysis of the amendment to the Criminal Code no. 333/2020 Coll., which has laid down a re-doubling of amounts of the individual limits of damages, as well as the analysis of the question whether it is possible to reconsider the link of damage to one of the flexible economic indicators in the conditions of Slovak or Czech Republic. Finally, the authors intend the need

* Štúdia je podporená Agentúrou na podporu výskumu a vývoja na základe Zmluvy č. APVV-150740 Návody a nástroje na efektívnu elimináciu protiprávnych konaní v spojení s možnou insolvenciou / Guidelines and tools for effective elimination of unlawful acts in relation with potential insolvency.

** Prof. JUDr. Jozef Čentéš, PhD., profesor a vedúci, Katedra trestného práva, kriminológie a kriminalistiky, Právnická fakulta, Univerzita Komenského v Bratislave; zástupca riaditela trestného odboru, Generálna prokuratúra Slovenskej republiky / Professor and Head, Department of Criminal Law, Criminology and Criminalistics, Faculty of Law, Comenius University in Bratislava, Slovak Republic; Deputy Director of the Criminal Matters Department of the General Prosecutor's Office of the Slovak Republic / E-mail: jozef.centes@flaw.uniba.sk / ORCID: 0000-0003-3397-746X

*** JUDr. Andrej Beleš, PhD., odborný asistent, Ústav európskeho práva, Právnická fakulta, Univerzita Komenského v Bratislave, Slovenská republika / Assistant professor, Institute of European Law, Faculty of Law, Comenius University in Bratislava, Slovak Republic / E-mail: andrej.beles@flaw.uniba.sk. / ORCID: 0000-0001-8418-0106

***Mgr. Jana Čipková, absolventka, Právnická fakulta, Univerzita Komenského v Bratislave, Slovenská republika / Graduate, Faculty of Law, Comenius University in Bratislava, Slovak Republic / E-mail: cipkova12@uniba.sk 
for an intertemporal provision, according to that penalties imposed before the effective date of the new Act shall remain unexecuted or shall be proportionately reduced.

\section{Keywords}

\section{Damage; Categorization of Damages; The Amount of Damage; Criminal Liability.}

\section{Úvod}

V roku 1987 - v súvislosti so zákonným vyjadrením a kategorizáciou škôd - Jiří Jelínek poznamenal: ,jde o problematiku neobyčejne životnou, dillę̌itou jak z teoretickébo blediska, tak $i$ z.pobledu legislativní či aplikační praxe. "1 Správnost' tohto výroku podčiarkuje idea načrtnutá v prvej časti štúdie, a teda, že od ostatného pojmoslovia všeobecnej časti zákona č. 300/2005 Z. z. Trestný zákon v znení neskorších predpisov (d’alej len „TZ SR“) a zákona č. 40/2009 Sb. trestní zákoník (d’alej len ,TZ ČR“) sa škoda výrazne odlišuje práve svojim finančným obsahom, fixne stanovenou sumou, ktorá svojou reálnou hodnotou nie je stála. ${ }^{2}$ To znamená, že plynutím rokov až desiatok rokov dochádza k významnej strate hodnoty peňazí pôsobením inflácie, čo skôr či neskôr musí byt' vyjadrené v právnej úprave vymedzenia škody. V opačnom prípade má pasivita zákonodarcu ${ }^{3}$ za dôsledok negatívny dopad na kvalifikáciu skutku, ako i určenie druhu trestu a jeho výmery, t.j. faktické latentné zostrovanie trestnej represie a kriminalizáciu konaní, ktoré by kedysi ešte stále neboli postihované trestnoprávnymi inštitútmi.

Úvodom je potrebné zopakovat' základné premisy, ktorých poznanie je dôležité pre obe časti štúdie:

1. Novela zákona č. 140/1961 Zb. Trestný zákon zákonom č. 175/1990 Zb. (d’alej len novela 1990) po prvýkrát zaviedla legálnu kategorizáciu škôd - v záujme idey spravodlivosti a rovnosti pred zákonom ${ }^{4}$. Stupne jednotlivých typov škôd pritom

1 Bližšie pozri JELÍNEK, J. Majetková škoda jako znak skutkové podstaty trestného činu. In: Socialistická zákonnost. Praha: Ministerstvo spravedlnosti ČSFR, 1987, roč. 35, č. 5, s. 263-277.

2 Uvedené je spôsobené meniacou sa kúpnou silou peňazí, infláciou. „Znamená to, ž̌e zatial’ č bude (napríklad)

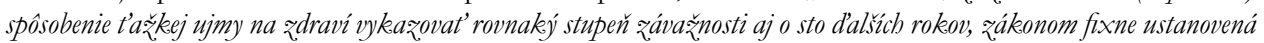
výška peñažnej sumy sa bude musiet prispôsobit?. Výška škody spôsobenej trestným čnom vyčslená na sumu 266,01€ v roku 2010 nebude vd'aka meniacej sa kípnej sile peñazi vykazovat' rovnakú (reálnu) hodnotu aj v roku 2050." Bližšie pozri ČENTÉŠ, J., A. BELEŠ a J. ČIPKOVÁ. Kategorizácia škôd spôsobených trestným činom (I. čast'). In: Casopis pro právni védu a praxi, Brno: Právnická fakulta Masarykovy univerzity, 2020, roč. 28, č. 2, s. 225-246. Dostupné z: https://journals.muni.cz/cpvp/article/view/13013

3 V Jelínkovom výklade táto „strnulá interpretácia hodnotiacich pojmov“ preukazuje, že zákonodarca pristupuje $\mathrm{k}$ majetkovej škode ako $\mathrm{k}$ účinku na hmotnom predmete útoku a nie ako $\mathrm{k}$ následku prejavujúcom sa na objekte trestného činu. JELÍNEK, J. Majetková škoda jako předmět zkoumání (z hlediska trestněprávního). In: Socialistická zákonnost. Praha: Ministerstvo spravedlnosti ČSFR, 1988, roč. 36, č. 8, s. 478-488.

$4 \mathrm{Na}$ nejednotné posudzovanie hraníc škôd $\mathrm{v}$ aplikačnej praxi upozorňovali napr. v roku 1980 Čič a Mathern: „Povedané Leninovými slovami, aby nedochádzalo k zákonnosti kazanskej a kalǔ̌skej, ale k jednotnému posudzovaniu v podstate rovnakých skutkov na celom územi federácie tak, ako to zodpovedá princípom zákeonnosti, idei spravodlivosti i rovnosti pred zákonom. "ČIČ, M. a V. MATHERN. Úvahy o výške škody v československom trestnom práve. Právny obžor, 1980, č. 1, s. 65-75. 
nadväzovali na výšku najnižšej mesačnej mzdy, neskôr minimálnej mesačnej mzdy. ${ }^{5}$ K zmene väzby na zákonom fixne ustanovenú peňažnú sumu pristúpil český zákonodarca s účinnost’ou od 1. januára 2002, zákonom č. 265/2001 Sb., ktorým sa novelizoval vtedajší TZ 1961. Na slovenskej strane sa tak stalo až rekodifikáciou trestného práva hmotného s účinnost'ou od 1. januára 2006. Od týchto momentov sa však vývoj škody v trestnom zákonodarstve oboch štátov takmer ${ }^{6}$ úplne zastavil.

2. V súčasnosti je pre slovenské trestné zákonodarstvo určujúcim ustanovením \ 125 ods. $1 \mathrm{TZ} \mathrm{SR}^{7}$ a štyri typy škôd. V Českej republike sa kategorizácia škôd člení do piatich typov, a to na základe $\int 138$ ods. 1 TZ ČR ${ }^{8}$.

3. S účelom reagovat' na celkový vývoj ekonomickej reality bol schválený zákon č. 333/2020 Sb., kterým se mění zákon č. 40/2009 Sb., trestní zákoník, ve znění pozdějších předpisů, zákon č. 141/1961 Sb., o trestním řízení soudním (trestní řád), ve znění pozdějších předpisů, a některé další zákony (d’alej len „Novela“), s účinnost'ou od 1. 10. 2020, ktorá ustanovila zdvojnásobenie súm určujúcich jednotlivé hranice výšok škôd. Slovenský zákonodarca zatial’ nepriniesol žiadne nové návrhy na zmenu TZ SR.

\section{Nález Ústavního soudu ČR zo dňa 26. 5. 2020, sp. zn. Pl. ÚS 46/18}

Aktualizačným momentom $\mathrm{v}$ porovnaní so stavom právnej úpravy, rozhodovacej činnosti súdov a právnej vedy v čase písania prvej časti tejto dvojdielnej štúdie je nález Ústavního soudu ČR zo dňa 26. 5. 2020, sp. zn. Pl. ÚS 46/18 (d’alej len „Nález“). Plénum ÚS ČR tu rozhodovalo o návrhu na zrušenie $\$ 138$ ods. 1 TZ ČR. Navrhovatel, Okresný súd v Liberci (d’alej len „Navrhovatel“"), vyjadril presvedčenie, že ustanovenie $\int 138$ ods. 1 TZ ČR sa v súčasnosti dostalo do priameho rozporu s čl. 40 ods. 6 Listiny, a to následkom

5 Ide len o zjednodušenú interpretáciu historického vývoja. Legálne vymedzenie kategorizácie škôd prešlo turbulentnými zmenami. Bližšie pozri BELEŠ, A. a N. HANGÁČOVÁ. Vývoj právnej úpravy hranice minimálnej škody. In: Notitia Iudiciales Academie Collegii Aedilium in Bratislava, Bratislava: Akadémia Policajného zboru v Bratislave, 2019, roč. 5, č. 1, s. 3-16.

6 O jemnej transformácii finančného obsahu škôd možno od uvedenej doby hovorit’ na území Slovenskej republiky. Rekodifikácia trestného práva hmotného s účinnost'ou od 1. januára 2006 stanovila hranicu medzi administratívnou a trestnou zodpovednost'ou ( $̌ k$ koda malâ) na sumu predstavujúcu 8000 Sk. S účinnost'ou od 1. januára 2009 (Zákonom č. 498/2008 Z. z., ktorým sa menia zákony v oblasti trestného práva v súvislosti so zavedením meny euro v Slovenskej republike) bola čiastka 8000 Sk $(265,55 €)$ novelizovaná na dnešných $266 €$ (z výkladu \ 125 ods. 1 TZ SR, s dôrazom na adjektívum „prevyšujúca“ sumu $266 €$, fakticky ide o sumu 266,01 €). Uvedená hodnota výšky škody malej sa teda nezmenila od 1. januára 2006 s výnimkou zanedbatel’nej korekcie k 1. januáru 2009, v rámci ktorej prišlo k zaokrúhleniu na celé eurá smerom nahor, a tým aj k nepatrnému zúženiu podmienok trestnosti.

7 Ust. \ 125 ods. 1 TZ SR: „Škodou malou sa rozumie škoda prevyšujúca sumu $266 €$. Škodou väčsou sa rozumie suma dosabujúca najmenej desat’násobok takej sumy. Značnou škodou sa rozumie suma dosabujúca najmenej stonásobok takej sumy. Škodou vel'kébo rozsabu sa rozumie suma dosabujúca najmenej pät'stonásobok takej sumy. "

8 Ust. S138 ods. 1 TZ ČR: „Škodou nikoli nepatrnou se rozumi škoda dosabujici ćástky nejméně 5000 Kč, škodou nikoli malou se rozumi škoda dosabujici ćástky nejméně $25000 \mathrm{~K}$ č, vétši škodou se rozumi škoda dosabujici ćástky nejméně $50000 \mathrm{Kč̆}$ żnačnou škodou se rozumi škoda dosabujici částky nejméně 500000 Kč a škodou velkého rozsahu se rozumi škoda dosabujici nejméné ćástky $5000000 \mathrm{Kčc}$ " 
rastu inflácie a celkovej životnej úrovne v Českej republike. Primárna argumentácia Navrhovatel'a tak korešponduje s (v d'alšom texte bližšie špecifikovanou) argumentáciou predkladatel'ov Novely, a tiež našou argumentáciou, ked' sa do popredia dostáva najmä potreba reflektovania ekonomických zmien do zákonnej kategorizácie škôd.

ÚS ČR návrh na zrušenie \138 ods. 1 TZ ČR, v slovách „Škodou nie nepatrnou sa rozumie škoda dosabujúca sumu najmenej $5000 \mathrm{~K}_{c}$ “, zamietol ${ }^{9}$. Avšak potrebu vyjadrenia ekonomických zmien do legislatívneho textu nijakým spôsobom nespochybňoval, práve naopak. Dôvod zamietavého verdiktu spočíval jednak

- v skutočnosti, že sprísnenie podmienok trestnej zodpovednosti (následkom dlhodobého „zakonzervovania“ právnej úpravy určujúcej hranice škôd) v spojení s vývojom inflácie nepredstavuje rozpor s princípmi vyjadrenými v čl. 40 ods. 6 Listiny $^{10}$, a jednak

- v rozsahu právomoci Ústavného súdu zasahovat' do normotvorby, ktorá podl'a ÚS ČR v zásade končí tam, kde začína výrazná pozícia zákonodarného orgánu v zmysle určovania trestnej politiky, čo ÚS ČR vyjadril nasledujúcimi úvahami: „Ústavnímu soudu samo o sobě neprísluší, aby posuzoval šíri hranic trestněprávní kriminalizace určitých typů jednání, nemá-li dublovat nebo suplovat ústavní roli zákonodárného orgánu [...] tento závěr lze bezpochyby vatahovat $i$ k nastaveni hranice kategorii škod uvedených v 138 trestního zákoníku, kteréje zásadní pro interpretaci znakì rady skutkových podstat trestných činu. [...] Nelze učnit závèr o protiústavnosti míry kriminalizace v prípadè, kdy v düsledku nečinnosti zákonodárce a faktických zmèn ekonomickébo rázu (zejména inflace) postačuje ke vyvozeni trestni odpovédnosti zpiosobeni škody fakticky menši, než k.terá byla predpokladem trestni odpovédnosti v minulosti. "11

Sudkyňa Kateřina Šimáčková a sudca Pavel Šámal však v spoločnom odlišnom stanovisku k odôvodneniu Nálezu zdôraznili, že aj zmena spoločenskej a ekonomickej situácie môže za určitých okolností viest' k zásahu Ústavného súdu. Tak sa však môže stat' len v prípade, ak je v dôsledku týchto zmien kriminalizované iné konanie než konanie pôvodne zamýšl'ané zákonodarcom, v dôsledku čoho môže dôjst' k porušeniu ústavného princípu nullum crimen, nulla poena sine lege zakotveného v čl. 39 Listiny. Ani podl'a tohto odlišného stanoviska však ekonomický rast nebol za súčasného posudzovania tak vel'ký, aby došlo k extrémnemu rozporu medzi pôvodným úmyslom zákonodarcu a formálne kriminalizovaným konaním po faktickej zmene následkom inflácie ${ }^{12}$, resp. neprišlo takému narušeniu zásady subsidiarity trestnej represie, že by nebolo dostatočné

9 Vo zvyšku bol návrh odmietnutý ako podaný osobou k tomu zjavne neoprávnenou, ked'že ostatná čast' 〔 138 ods. 1 TZ ČR netvorila právny podklad pre rozhodovanie Okresného súdu v Liberci, ani priamo neovplyvňovala priebeh konania vedeného týmto súdom, Navrhovatel’om (dôsledok aplikácie čl. 95 ods. 2 Ústavy ČR a \ 64 ods. 3 Zákona č. 182/1993 Sb. o Ústavním soudu).

10 Pozri najmä body 34 až 38 Nálezu.

11 Body 31 a 33 Nálezu.

12 Bod 9 odlišného stanoviska. A contrario, takáto situácia by prichádzala do úvahy v prípade hyperinflácie, bod 5 odlišného stanoviska. 
aplikovat’ hmotnoprávne či procesnoprávne korektívy trestného práva. Uvedené nás pritom vedie k d’alšej zásadnej otázke, ktorá bola týmto Nálezom definitívne otvorená.

Diskutabilným sa ukázalo byt’ posudzovanie možnosti primeranej aplikácie niektorého z korektívov trestnej zodpovednosti, či už ide o tzv. hmotnoprávny korektív v podobe $\mathbb{} 12$ ods. 2 TZ ČR alebo o tzv. procesnú oportunitu podl'a $\mathbb{S} 172$ ods. 2 písm. c) T' $\check{\mathbf{R}}^{13}$, na situácie, ked’ škoda spôsobená konaním páchatel’a len mierne prevyšuje hranicu škoody nikoli nepatrnej, t. j. hranicu 5000 Kč. V uvedenej otázke sa pritom nerozchádzajú len názory Navrhovatel’a s Nálezom ÚS ČR, ale aj obe odlišné stanoviská k odôvodneniu Nálezu, a teda odlišné stanovisko sudcu Jaroslava Fenyka a spoločné odlišné stanovisko sudkyne Kateřiny Šimáčkové a sudcu Pavla Šámala.

Navrhovatel' (bod 9 Nálezu) bol presvedčený, že pevné hranice stanovené v \ 138 ods. 1 TZ ČR nemožno preklenút' či prelomit' aplikáciou zásady subsidiarity trestnej represie. ÚS ČR však (bod 33 Nálezu) zhodne s vyjadrením vlády (bod 14 Nálezu) vyslovil, že v prípade odôvodnenosti ich použitia, poskytujú oba korektívy dostatočný priestor pre interpretáciu formálnych znakov jednotlivých trestných činov.

S obsahom bodu 33 Nálezu sa však nestotožnil sudca Fenyk, ktorý vyjadril nesúhlas s možnost'ou primeraného použitia $\int 12$ ods. 2 TZ ČR. Meritum jeho argumentácie spočívalo v tom, že zákonodarca stanovil hranice trestnosti jednoznačným a nespochybnitel'ným spôsobom, z ktorého dôvodu sa škoda dosahujúca hranicu zákonom predpísanej škody pre znak danej skutkovej podstaty nemôže vymykat’ onej „spodnej hranici trestnosti“" v zmysle \138 ods. 1 TZ ČR. Proti primeranému použitiu tzv. procesnej oportunity podl’a $\int 172$ ods. 2 písm. c) TŘ, ako korektívu, ktorý nezasahuje do viny, ale má len procesný oportunitný charakter, sudca Fenyk nevzniesol zásadné pripomienky.

Bludný kruh rôznorodosti názorov napokon uzatvára odlišné stanovisko sudkyne Šimáčkové a sudcu Šámala, ktoré v úplnom kontraste so stanoviskom sudcu Fenyka dokonca preferuje možnost' aplikácie \12 ods. 2 TZ ČR pred aplikáciou \172 ods. 2 písm. c) TŘ. K samej možnosti aplikácie $\int 12$ ods. 2 TZ ČR možno podl'a spoločného vyjadrenia sudcov dodat', že sama skutočnost', že zákonodarca jasne stanovil hranice škody nikoli nepatrnej nijako neobmedzuje možnost' aplikácie $\int 12$ ods. 2 TZ ČR-formálne znaky trestného činu by síce mali byt' vyjadrené jasne a určito v súlade so zásadou nullum crimen sine lege certa, no hmotnoprávny korektív obsiahnutý v \12 ods. 2 TZ ČR je súdmi posudzovaný až po dosiahnutí záveru, že formálne znaky trestného činu boli naplnené. Aplikácia tohto ustanovenia tak v takýchto prípadoch nie je prelomením „,pevne daných

13 TZ SR neustanovuje úpravu princípu ultima ratio, tak ako $\int 12$ ods. 2 TZ ČR, obdobou je jeho pripustenie vo sfére tzv. materiálnej protiprávnosti trestného činu, teda pri posudzovaní závažnosti prečinov v rámci \10 ods. 2 TZ SR (materiálny korektív). Česká právna úprava - na rozdiel od slovenskej - obsahuje aj v Náleze uvedený procesný korektív v zmysle \ 172 ods. 2 písm. c) TRŘ, ktorého podstatou je neúčelnost' stíhania páchatel’a. Bližšie pozri MULÁK, J. Základní zásady trestního ř́zeni a právo na spravedlivý proces. Praha: Leges, 2019, s. 140 a nasl. 
mantinelov stanovených v $\int 138$ ods. 1 TZ ČR“, len bežnou aplikáciou tejto zásady, ktorá sa musí prispôsobovat' ako konkrétnym podmienkam posudzovaného prípadu, tak i premieňajúcej sa spoločenskej situácii v zmysle právnej doktríny de minimis non curat praetor. V súvislosti s preferenciou použitia \12 ods. 2 TZ ČR pred použitím \ 172 ods. 2 písm. c) TRŘ sudcovia vyzdvihujú dôraz, ktorý treba prikladat' na hmotnoprávny korektív, ked’že v dôsledku jeho aplikácie dôjde k uplatneniu „aspoň nejakej“ verejnoprávnej zodpovednosti páchatel’a, hoci nie tej trestnej. Oproti tomu procesný korektív vedie $\mathrm{k}$ zastaveniu trestného stíhania, a tým aj $\mathrm{k}$ neuplatneniu akejkol’vek zodpovednosti páchatel'a vo sfére verejného práva. Sudcovia uvedené ilustrujú na situácii, ked' by mohol byt' páchatel' potrestaný v priestupkovom konaní za konanie, ktorým spôsobil škodu tesne pod zákonom stanovenú hranicu škoody nikoli nepatrnej, ale nebol by potrestaný vôbec, ak by spôsobil škodu l’ahko prevyšujúcu hranicu škody nikoli nepatrnej.

I napriek rozmanitosti názorov a ich odôvodnení, na záver vyjadrujeme súhlas s argumentáciou sudkyne Kateřiny Šimáčkové a sudcu Pavla Šámala, ktorá rozširuje bod 33 Nálezu, a teda presvedčenie, že v odôvodnených prípadoch by malo byt' nielen možné, ale aj žiadúce - v záujme zmierňovania tvrdosti zákona, aplikovat' hmotnoprávny korektív podl’a \ 12 ods. 2 TZ ČR, a to aj napriek zdanlivo prísne stanoveným formálnym kritériám \ 138 ods. 1 TZ ČR. To najmä s poukazom na to, že naplnenie formálnych znakov skutkovej podstaty trestného činu per se nemôže bránit’ uplatneniu materiálneho korektívu; v opačnom prípade by tento právny inštitút bol neaplikovatel'ný, ked’že sa aplikuje až po zistení, že formálne znaky skutkovej podstaty boli naplnené. Právna možnost' zmierňovat' tvrdost' zákona vzhl'adom na okolnosti prípadu navyše nemôže závisiet' od stupňa určitosti a presnosti znakov skutkovej podstaty trestných činov. Zákonodarca v rámci svojej úvahy stanovil viac alebo menej určité podmienky trestnosti a zároveň dal súdu oprávnenie vykonat’ úvahu o aplikácii trestnej represie v rámci svojho priestoru prostredníctvom materiálneho korektívu.

\section{Novela TZ ČR, ktorá ustanovuje zdvojnásobenie súm určujúcich jednotlivé hranice výšok škôd}

Poukazujúc na úplný úvod tejto štúdie, prijal Parlament Českej republiky Novelu, ktorá zahŕňa plošný nárast všetkých piatich hraníc výšok škôd o dvojnásobok. S viacerými tvrdeniami vyplývajúcimi z dôvodovej správy ${ }^{14}$ sa pritom autori tejto štúdie stotožňujú. Na druhej strane však, dôvodová správa obsahuje aj tvrdenia, s ktorými nemožno plne súhlasit'.

14 Dôvodová správa k Novele neobsahuje vysvetlivky k navýšeniu jednotlivých hraníc typov škôd. Návrh Novely bol totiž zlúčený s návrhom poslancov na vydanie zákona, ktorým se mení zákon č. 40/2009 Sb., trestní zákoník. Pozri dôvodovú správu k Návrhu poslancov na vydanie zákona, ktorým se mení zákon č. 40/2009 Sb., trestní zákoník, ve znění pozdějších předpisů, zákon č. 141/1961 Sb., o trestním řízení soudním (trestní řád), ve znění pozdějších předpisů, a zákon č. 418/2011 Sb., o trestní odpovědnosti právnických osob a řízení proti nim, ve znění pozdějších předpisů. Poslanecká sněmovna [online]. [cit. 19. 3. 2020]. Dostupné z: https://www.psp.cz/sqw/text/tiskt.sqw?O=8\&CT=466\&CT1=0\&fbclid=IwAR3ypv1zsvgoEhxq7GssXV9bAusRQVh58UDjw0c0Sc-naeWAwvzhFuLhQ3M 
Od 1. januára 2002 došlo k navýšeniu miery inflácie o viac než 30\% bez toho, aby mala táto skutočnost' akýkol’vek vplyv na ustanovenie $\int 138$ ods. 1 TZ ČR. To viedlo ku skrytému, ale vel'mi citlivému zostrovaniu trestnej represie a faktickej kriminalizácii konaní, ktoré by v roku 2001 nedosahovali trestnoprávny rozmer. V d’alšom texte sa dôvodí historickým vývojom, a teda viac ako dekádu trvajúcou väzbou na ukazovatel' minimálnej mesačnej mzdy či dynamikou rastu priemernej hrubej mesačnej mzdy. Je však spôsob plošného zdvojnásobenia súm určujúcich jednotlivé hranice výšok škôd tou najvhodnejšou cestou?

Tabul'ka č. 1: Navýšenie jednotlivých hraníc typov škôd podl’a Novely

\begin{tabular}{|c|c|c|c|c|c|}
\hline Škoda & nikoli nepatrná & nikoli malá & větší & značná & $\begin{array}{l}\text { velkého } \\
\text { rozsahu }\end{array}$ \\
\hline $\begin{array}{l}\text { Od 1. 1. } 2002 \\
\text { do 30. } 9.2020\end{array}$ & $5000 \mathrm{Kč}$ & $25000 \mathrm{Kč}$ & $50000 \mathrm{Kč}$ & $500000 \mathrm{Kč}$ & $5000000 \mathrm{Kč}$ \\
\hline Novela & $10000 \mathrm{Kč}$ & $50000 \mathrm{Kč}$ & $100000 \mathrm{Kč}$ & $1000000 \mathrm{Kč}$ & $10000000 \mathrm{Kč}$ \\
\hline
\end{tabular}

\section{Inflácia vs. minimálna a priemerná mzda}

Ked’že v štúdii argumentujeme najmä infláciou, a tým aj odlišným náhl’adom na použitie minimálnej a priemernej mzdy v trestnom zákonodarstve, je potrebné začat' krátkym rozborom.

Vzhl’adom na historickú kontinuitu viazania výšky škody na minimálnu mesačnú mzdu, zákonodarca $\mathrm{v}$ dôvodovej správe $\mathrm{k}$ Novele argumentuje jej prudkým rastom v kontraste s dlhodobo stagnujúcimi výškami súm jednotlivých typov škôd. Na tom by nebolo nič nesprávne, keby išlo len o konštatovanie dávnej tradície, a nezdalo sa, že práve táto je činitel'om, ktorému bola Novela prispôsobovaná. ${ }^{15}$ Minimálna mzda rastie v ostatných rokoch výrazne rýchlejšie ako inflácia, a dokonca aj ako priemerná mzda ${ }^{16}$, čo je viac dôsledkom politických zásahov než odrazom ekonomickej reality. ${ }^{17}$

15 Vtedajší minister spravodlivosti ČR, Jan Kněžínek, napríklad v rozhovore pre ČT 24 poznamenal: „Když si vez̧mu pomèr mezi minimálni mźdou a 5000 korunami tehdy a dnes, tak se mi jevi optimální hranici trestnébo činu vynásobit dvěma. "Viz Hranice trestného činu má začínat na deseti tisících, plánuje ministr spravedlnosti. Ceská televize [online]. [cit. 23. 3. 2020]. Dostupné z: https://ct24.ceskatelevize.cz/domaci/2641664-knezinek-hranice-trestneho-cinu-ma-byt-az-10-tisic-korun-lide-dnes-zbytecne-konci-ve

16 Od roku 2014 sa roztvárajú nožnice medzi rýchlejším rastom priemernej nominálnej mzdy a pomalším rastom produktivity práce. Minimálna mzda rastie rýchlejšie ako priemerná. Napríklad v roku 2018 rástla priemerná mzda približne o $6 \%$ medziročne, minimálna stúpla o $10 \%$. Bližšie pozri Prudký rast minimálnej mzdy brzdí pokles nezamestnanosti a poháňa infláciu. Inštitút pre ekonomické a sociálne reformy [online]. [cit. 23. 3. 2020]. Dostupné z: http://www.ineko.sk/clanky/ prudky-rast-minimalnej-mzdy-brzdi-pokles-nezamestnanosti-a-pohana-inflaciu

17 Uvedené potvrdzuje aj graf kumulatívneho rastu produktivity práce, priemernej a minimálnej mzdy (do roku 2019). Denník $N$ [online]. [cit. 23. 3. 2020]. Dostupné z: https://a-static.projektn. sk/2019/12/4W5yS-kumulat-vny-rast-produktivity-pr-ce-priemernej-a-minim-lnej-mzdy-v-nbsp-nbsp-. png 
Ukazovatele podobné minimálnej mzde stoja však v každej krajine na odlišnom základe. Zatial' čo v pol'skom trestnom zákonodarstve môže plnit' svoju funkciu (k tomu pozri text nasledujúcej časti - pozn. autorov), tak ani na Slovensku, ani v Českej republike nie je väzba na minimálnu mesačnú mzdu dlhodobo udržatel’ná, čo v dôvodovej správe k zákonu č. 265/2001 Sb. uviedol aj sám český zákonodarca. ${ }^{18}$ Predpoklad, že nadviazaním na tento činitel' bude trestné právo pružnejšie reagovat' na inflačný vývoj bol v priebehu rokov vyvrátený. Ďalší dôvod pre jej elimináciu tvoril nesúlad s medzinárodnoprávnou garanciou nullum crimen sine lege ${ }^{19}$ scripta $^{20}$, čo by však samozrejme nebránilo v poukazovaní na jej finančný obsah.

Každým rokom sa mení kúpna sila peňazí (inflácia), a teda aj cena veci, na ktorej môže byt' trestným činom spôsobená škoda. Tá je potom logicky vyčíslená tiež vo vyššej sume, než ako tomu bolo pred niekol'kými rokmi. ${ }^{21} \mathrm{I}$ ked' korelácia s priemernou mzdou je v každom prípade na mieste, zastávame názor, že na legislatívne vymedzenie škody je prijatel'nejšie nahliadat' cez optiku reálneho nárastu škôd spôsobených trestnou činnost'ou. Teda nie cez optiku zvyšujúcej sa životnej úrovne obyvatel’stva, resp. akéhosi faktického vyjadrenia ujmy pocit'ovanej poškodeným. Ešte o niečo zásadnejším argumentom je skutočnost', že pomocou naviazania na činitel’ inflácie sa kritériá podmienok trestnej zodpovednosti zužujú pomalšie, čím z roka na rok predchádza k skokovému nárastu súm určujúcich zákonnú kategorizáciu škôd. Toto treba pokladat’ za podstatné poznatky z hl'adiska právnej úpravy výšky škody v trestnom zákonodarstve.

\section{Tendencie v zákonodarstve okolitých štátov}

Aby sme k záverom vedeli pristupovat' čo najviac konštruktívne, prihliadli sme k úpravám zákonnej kategorizácie škôd v štátoch susediacich so Slovenskou republikou a Českou republikou - najmä v Pol’sku, Mad'arsku a na Ukrajine. Každá z uvedených

18 Dôvodová správa k zákonu č. 265/2001 Sb., ktorým se mení zákon č. 141/1961 Sb., o trestním řízení soudním (trestní řád), ve znění pozdějších předpisů, zákon č. 140/1961 Sb., trestní zákon, ve znění pozdějších předpisů, a niektoré d’alšie zákony. Dostupné z: ASPI [právny informačný systém].

19 KRESS, C. Nulla poena nullum crimen sine lege. In: Max Planck Encyclopedia of Public International Law [online]. Heidelberg: Oxford University Press, 2010, s. 10 [cit. 24. 3. 2020]. Dostupné z: http:// www.uni-koeln.de/jur-fak/kress/NullumCrimen24082010.pdf

20 Nesúladom s čl. 49 Ústavy Slovenskej republiky: „Len zákon ustanoví, ktoré konanie je trestným činom a aký trest, prípadne iné ujmy na právach alebo majetku možno uložit’ za jeho spáchanie. ", a tým aj čl. 39 Listiny základných práv a slobôd, dôvodil pri vyradení minimálnej mesačnej mzdy aj slovenský zákonodarca. Bližšie pozri Dôvodová správa k zákonu č. 300/2005 Z. z. Trestný zákon v znení neskorších predpisov. Národná rada SR [online]. [cit. 20.3. 2020]. Dostupné z: https://www.nrsr.sk/web/Default.aspx?sid=zakony/zakon\&MasterID=1612

21 Napr. škoda na veci v hodnote 5000 Kč v roku 2002 by pod vplyvom inflácie v roku 2019 zodpovedala sume 7010 Kč. Uvedený prepočet vyplýva z inflácie za obdobie 2002-2019, inflácia sa zvýšila o cca $39 \%$. Údaje vyplývajú z priemernej ročnej miery inflácie pre roky 2002-2019 každoročne zverejnenou ČSÚ. Viz Inflace - druhy, definice, tabulky. Ceský statistický úrad [online]. [cit. 21. 3. 2020]. Dostupné z: https:// www.czso.cz/csu/czso/mira_inflace; S prepojením na tieto údaje pracuje aj Kalkulačka inflace. penize.cz. [online]. [cit. 21. 3. 2020]. Dostupné z: https://www.penize.cz/kalkulacky/znehodnoceni-koruny-inflace 
právnych úprav obsahuje aspekt dopomáhajúci k d’alším častiam. Rakúsko a Nemecko všeobecne neupravujú ustanovenia o osobitnej kategorizácii škôd, resp. neustanovujú hranicu minimálnej škody pre vznik trestnej zodpovednosti. V tomto smere neboli zaregistrované ani žiadne d’alšie prvky pre nás inšpiratívnej právnej úpravy. Vd’aka vyspelosti ich ekonomiky nemožno prihliadat' ani na čiastky tvoriace hranice jednotlivých typov škôd - vzhl'adom na ich vyššie úrovne.

Rakúske trestné zákonodarstvo uplatňuje väzbu na fixnú peňažnú čiastku en bloc v prípadoch, kedy to zákonodarca považuje za potrebné, a v rozsahu, aký považuje (vzhl’adom na predpokladaný rozsah trestnej činnosti posudzovaného deliktu) za vhodný. T.j. v trestnom zákonníku Rakúska Strafgesetz̧uch $(\mathrm{StGB})^{22}$ sa v rámci jednotlivých trestných činov ako kvalifikačné znaky (obzvlášt' prit’ažujúce okolnosti)objavujú čiastky $3000 €^{23} ; 5000 €^{24}$; $50000 €^{25} ; 300000 €^{26}$ či $1000000 €^{27}$. Hranicu minimálnej škody rakúsky trestný zákonník StGB neobsahuje, avšak ustanovuje osobitnú úpravu majetkovej kriminality, ak ide o veci nepatrnej hodnoty, konkrétne privilegovanú skutkovú podstatu trestného činu odcudzenia veci (Entwendung) podl’a \141. Špecifickými znakmi skutkovej podstaty tohto trestného činu sú motív: spáchanie činu z núdze, nerozvážnosti alebo na uspokojenie túžby, predmet útoku: vec nepatrnej hodnoty, resp. odkaz na iné trestné činy, ktoré by inak mohli byt' pri absencii týchto znakov spáchané: krádež, neoprávnený odber energie, sprenevera, zatajenie veci, neoprávnené užívanie cudzej veci a zásah do loveckého a rybárskeho práva. Podl'a tohto ustanovenia tak môže byt' napr. kvalifikovaná krádež cukroviniek v hodnote $5,11 €$, ak páchatel' konal v pohnútke uspokojit' svoj hlad. ${ }^{28}$ Definícia pojmu vec nepatrnej hodnoty je ponechaná na aplikačnú prax a právnu vedu, čo je riešenie podobné československému právnemu stavu do účinnosti novely 1990 - za dolnú hranicu bola považovaná suma $100 \mathrm{Kčs}$, inokedy $300 \mathrm{Kčs}$ alebo aj $50 \mathrm{Kčs}^{29}$. V praxi i literatúre v podmienkach

22 Bundesgesetz vom 23. Jänner 1974 über die mit gerichtlicher Strafe bedrohten Handlungen (Strafgesetzbuch - StGB) StF: BGBl. Nr. 60/1974, das zuletzt durch Artikel 62 des Gesetzes vom 20. November 2019. BGBl. I S. 1626. geändert worden ist, Strafgesetzbuch - StGB.

23 Napr. \304 ods. 2 (úplatkárstvo) rakúskeho trestného zákonníka StGB: „Kto spácha trestný čin vo vz̧’ahu k hodnote úplatku prevyšujúcej $3000 €,[\ldots]$ "

24 Napr. \132 ods. 2 (neoprávnený odber energie) rakúskeho trestného zákonníka StGB: „Kto odoberá energiu, ktorej hodnota presahuje $5000 €,[\ldots]$ "

25 Napr. \304 ods. 2 (úplatkárstvo) rakúskeho trestného zákonníka StGB: „,...]a kto sa dopusti konania vo vzt'ahu ke hodnote úplatku $50000 €$, [...]".

26 Napr. \132 ods. 2 (neoprávnený odber energie) rakúskeho trestného zákonníka StGB: „, [...] a kto odoberá energiu v hodnote viac ako $300000 €,[\ldots]$ ".

27 Napr. \ 159 ods. 4 bod 1 (poškodzovanie záujmov veritel'a hrubou nedbanlivost'ou) nemeckého trestného zákona („Strafgesetzbuch“): „Odňatím slobody až na dva roky sa páchatel' potrestá, ak spácha čin uvedený $v$ odseku 1 a neuspokojenie veritel'ov prekroči sumu $1000000 €,[\ldots]$. "

28 Der Oberste Gerichtshof (najvyšší súd) zo dňa 4. decembra 2019, sp. zn. 15Os123/19f.

29 ČIČ, M. a V. MATHERN. Úvahy o výške škody v československom trestnom práve. Právny obzor, 1980 , č. 1 , s. $65-75$. 
rakúskeho práva je možné identifikovat' nejednotný prístup k tejto otázke: pôvodná hranica 500 rakúskych šilingov, neskôr 1000 rakúskych šilingov (ako desatina kvalifikačného znaku) sa pretransformovala na $72 €$, neskôr $100 €^{30}$, avšak uvádza sa aj hranica $300 €$ (opät' ako desatina kvalifikačného znaku) ${ }^{31}$. Zohl'adňuje sa však aj citel'nost' škody pre poškodeného, preto z pojmu vec nepatrnej hodnoty môže byt' vylúčená aj vec, ktorá má nižšiu hodnotu ako $100 €(300 €)$. Ustanovenou sankciou je trest odňatia slobody až na jeden mesiac alebo peňažný trest do výšky 60 denných sadzieb.

Za zaujímavost' nemeckého trestného práva (nemecký trestný zákonník Strafgesetz̧buch $\mathrm{StGB}^{32}$ ) možno zasa považovat', že namiesto minimálnej škody pri niektorých trestných činoch majetkovej povahy vyžaduje na začatie trestného stíhania návrh poškodeného, teda vlastníka veci ${ }^{33}$ (okrem prípadov osobitného verejného záujmu), a to pri krádeži veci či sprenevere veci nepatrnej hodnoty (geringwertige Sache) podl’a $\$ 248$ a nemeckého trestného zákonníka StGB. Adekvátne sa toto ustanovenie aplikuje aj pri d’alších trestných činoch. ${ }^{34}$ Pojem vec nepatrnej hodnoty nie je zákonne definovaný a - podobne ako v rakúskom právnom stave - je ponechaný na aplikačnú prax a právnu vedu. V porovnaní s rakúskym je však nemecký prístup podstatne prísnejší. V 90-tych rokoch sa za hranicu nepatrnosti považovalo 50 nemeckých mariek, čo zodpovedalo sume $25 €$, avšak prijímanou hodnotou je aj hranica $30 €(2018)^{35}$ a v súčasnosti až $50 €^{36}$. Veci, ktoré nemajú meratel'nú obchodnú hodnotu, ale ich hodnota spočíva vo funkčnom použití (napr. spisy, občiansky preukaz a pod.) nie sú vecmi nepatrnej hodnoty. ${ }^{37} \mathrm{~V}$ trestnom stíhaní pritom často dochádza k využívaniu zásady oportunity. ${ }^{38}$ Prvkom oportunity je odklon od štandardného priebehu trestného stíhania podl’a \ 153 nemeckého trestného poriadku Strafprozessordnung StPO ${ }^{39}$. Podstatou odklonu je upustenie od trestného stíhania pre nepatrnú závažnost'

30 A S. REINDL-KRAUSKOPF. Strafrecht Besonderer Teil I. Delikete gegen den Einzelnen (Leib und Leben, Freibeit, Ehre, Privatsphäre, Vermögen). 3., přepracované a doplněné vyd. Wien: Springer-Verlag, 2009, s. 129, 146.

31 BERTEL, Ch. a K. SCHWEIGHOFER. Österreichisches Strafrecht Besonderer Teil I. $\int 75$ bis 168 e StGB. 11., zcela přepracované vyd. Wien: Springer-Verlag, 2010, s. 234.

32 Strafgesetzbuch in der Fassung der Bekanntmachung vom 13. November 1998 (BGB1. I S. 3322), das zuletzt durch Artikel 1 des Gesetzes vom 3. März 2020 (BGBl. I S. 431) geändert worden ist.

33 MITSCH, W. Strafrecht, Besonderer Teil 2. Vermögensdelikte. 3. vyd. Heidelberg: Springer-Verlag, 2015, s. 141.

34 Nadržovanie (Begünstigung, \257), úžera (Heblerei, \259), podvod, (Betrug, \263), zatajenie výnosov (Erschleichen von Leistungen, \265a), porušovanie povinností pri správe cudzieho majetku (Untreue, \266).

35 FISCHER, T. Strafgesetz̧buchmitNebengesetzen. München: C. H. Beck, 2018, s. 1798.

36 MAVANY, M. \153. In: BECKER, J.-P., ERB, V., ESSER, R., GRAALMANN-SCHEER, K, HILGER, H., IGNOR, A.: DieStrafprozeßordnungund das Gerichtsverfassungsgesetz. Großkommentar. 27., neubearbeiteteAuflage. Berlin: De Gruyter, 2020, s. 100.

37 Bližšie FISCHER, T.: StrafgesetzbuchmitNebengesetzen. München: C. H. Beck, 2018, s. 1798.

38 MAREŠOVÁ, A. Resortnistatistiky - zákeladni zudroj informací o keriminalitě v České republice. Praha, IKSP, 2011 , s. 64.

39 Strafprozeßordnung in der Fassung der Bekanntmachung vom 7. April 1987 (BGBl. I S. 1074, 1319), die zuletzt durch Artikel 2 des Gesetzes vom 3. März 2020 (BGBl. I S. 431) geändert worden ist. 
trestného činu (Absehen von der VerfolgungbeiGeringfügigkeit). ${ }^{40}$ Nepatrnost' v procesnom práve sa obsahovo viaže na nepatrnost' v hmotnom práve. ${ }^{41}$

Ďalšie hranice škôd ako kvalifikačné znaky (obzvlášt' prit’ažujúce okolnosti) neustanovuje nemecký trestný zákonník StGB ako rakúsky predpis presnými peňažnými sumami, ale všeobecnými znakmi, najmä znakom v obzulášt závažných prípadoch ${ }^{42}$, ktoré sa spravidla neviažu na konkrétnu výšku spôsobenej škody, ale iné okolnosti zvyšujúce závažnost' činu (najmä remeselné páchanie trestného činu, spáchanie činu organizovanou skupinou atd’.).

Nemecký spolkový ústavný súd (Bundesverfassungsgericht) aj v súvislosti s krádežou veci nepatrnej hodnoty ${ }^{43}$ (konkrétne krádežou potravín v hodnote 4,69 nemeckých mariek) vyslovil v roku 1979, že nemecký trestný zákonník StGB neustanovuje v týchto prípadoch neprimerane prísny postih, ktorý by bol nezlúčitel'ný s ústavnými kautelami Základného zákona (Grundgesetz). ${ }^{44}$ Ústavný súd pripomenul, že \248a nemeckého trestného zákonníka StGB, ktorý upravuje režim vecí nepatrnej hodnoty, nie je privilegovanou skutkovou podstatou trestného činu, ale je ustanovením, ktoré zakladá osobitný procesný režim stíhania len na návrh. S poukazom na výklad vyššie - toto považujeme za zásadný rozdiel medzi nemeckou a rakúskou právnou úpravou. Potláčanie bagatel’nej kriminality zostáva podl'a ústavného súdu vo sfére uváženia zákonodarcu, resp. zákonodarca nie je povinný právnu úpravu krádeží vecí nepatrnej hodnoty vyňat' z trestného práva a zahrnút' do priestupkového práva (Ordnungswidrigkeitenrecht). Hoci Ústavní soud ČR v náleze sp. zn. Pl. ÚS 46/18 priamo neodkazuje na predmetné dávnejšie rozhodnutie nemeckého spolkového ústavného súdu, jadro myšlienky o neprípustnosti dublovania alebo suplovania ústavnej úlohy zákonodarcu je totožné.

Ako podotýka nemecký spolkový ústavný súd, uvedené platí aj s ohladom na skutočnost', že neexistujú ustálené kriminologické poznatky, ktoré by jednoznačne určovali vhodnost' riešenia bagatel'nej kriminality určitým spôsobom a ktoré by vzhl'adom na ústavné princípy mal zákonodarca povinnost' zohl’adnit'. Zákonodarca mal tak v rámci svojho uváženia pri zohl'adnení spoločenskej závažnosti bagatel'nej kriminality nasledujúce možnosti: zavedenie privilegovaných skutkových podstát v osobitnej časti alebo ustanovenie osobitných sankcií (príp. zásad ukladania trestov) vo všeobecnej časti trestného zákonníka alebo $\mathrm{v}$ trestnoprocesnej úprave obmedzenie zásady legality (Verfolgungsžnang) prvkom

40 Podla $\int 153$ nemeckého trestného poriadku StPO je oprávnený rozhodnút' o odklone štátny zástupca (prokurátor) so súhlasom súdu. Súhlas súdu sa nevyžaduje, ak ide o prečin v základnej skutkovej podstate a následky činu sú nepatrné.

41 MAVANY, M. \153. In: BECKER, J-P., V. ERB, R. ESSER, K. GRAALMANN-SCHEER, H. HILGER, a A. IGNOR. DieStrafprozeßordnungund das Gerichtsverfassungsgeset: Großkommentar. 27., nově přepracované vyd. Berlin: De Gruyter, 2020, s. 100.

42 „In besonders schweren Fällen [...]“" Napr. trestný čin podvodu podla \263 ods. 3 nemeckého StGB.

43 Ust. $\ 242$ v spojení s ust. $\ 248$ a nemeckého StGB.

44 Beschluß, Bundesverfassungsgericht (uznesenie Spolkového ústavného súdu), BVerfGE 50, 205 Strafbarkeit von Bagatelldelikten, 17. Januar 1979, 2 BvL 12/77. 
oportunity, možnost'ou aplikovat' odklon v trestnom stíhaní. Ústavný súd poznamenal, že zákonodarca si vybral procesualistické riešenie (\153 nemeckého trestného poriadku StPO) v kombinácii s priznaním postavenia bagatel’ných deliktov ako návrhových deliktov. Samotný trestný postih bagatel'nej kriminality (s trestnou sadzbou pri krádeži v rozmedzí až na pät' rokov) nie je v rozpore s požiadavkou primeranosti trestania, ktorá má ústavnoprávny rozmer. České a slovenské riešenie so zákonne stanovenými hranicami minimálnej škody, resp. s vylúčením bagatel'ných deliktov do administratívneho postihu spolkový ústavný súd nezvažoval. Všeobecné súdy si uvedené východiská osvojili vo svojej rozhodovacej činnosti. Spolkový najvyšší súd (Bundesgerichtshof) ${ }^{45}$ konštatuje, že pri bagatel'ných deliktoch nie je per se vylúčené (teda nie je neprimerané) ani uloženie krátkodobého trestu odňatia slobody: vždy je nevyhnutné rozhodnút' podl’a okolností konkrétneho prípadu.

Mad'arsko člení typy škôd do piatich kategórií podl'a \ 459 ods. $6^{46}$ mad'arského trestného zákona ${ }^{47}$, pričom hranicou medzi administratívnou a trestnou zodpovednost'ou je, podobne ako v podmienkach slovenského právneho poriadku, škoda malá predstavujúca sumu medzi $50001 \mathrm{HUF}\left(149,04 €^{48}\right)$ a $500000 \mathrm{HUF}(1490,40 €)$. Najprísnejším kvantifikantom je škoda obzvlášt' značná predstavujúca sumu nad 500000001 HUF (1 490 401,82 €). Je zrejmé, že z hladiska systému trestným zákonom ustanovených hraníc škôd je mad’arská právna úprava voči slovenskej a českej najviac príbuzná, ked’ nadväzuje výlučne na pevnú peňažnú sumu.

Ak hovoríme o minimálnej hranici potrebnej na vyvodenie trestnej zodpovednosti v Pol'sku, je potrebné siahnut' po pol'skom priestupkovom zákone ${ }^{49}$, ktorý vo svojom čl. 119 ods. 1 považuje za pomyselnú deliacu čiaru medzi priestupkom a trestným činom, najmä pri drobných krádežiach, sumu 500 PLN (116,17€), ked' ustanovuje, že kto odcudzí hnutel'ný majetok niekoho iného a hodnota nepresiahne 500 PLN, skutok sa kvalifikuje ako priestupok. Najprísnejší kvalifikačný znak skutkovej podstaty podl'a pol'ského trestného zákona ${ }^{50}$ je škooda vel’kého roșahu prevyšujúca sumu 1000000 PLN

45 Beschluss, Bundesgerichtshof (uznesenie spolkového najvyššieho súdu), 4 StR 400/07 z 15. novembra 2007. Krádež vecí nepatrnej hodnoty v predmetnom prípade spočívala v prisvojení si dvoch fliaš piva každá v hodnote po $0,62 €$.

46 Ust. \ 459 ods. 6 zákona 212/C (2012. évi C. törvény a Büntető Törvénykönyvről): „Na účely tohto zákona sa pod pojmom hodnota, škoda a majetková ujma rozumie nasledujúce:

a) medzi 50 tisic HUF a 1 forint a 500 tisic HUF je malá,

b) medzi 500 tisic HUF a 1 forint a 5 miliónov HUF vel'ká,

c) medzi 5 miliónov HUF a 1 forint a 50 miliónov HUF značná,

d) medzi 50 miliónov HUF a 1 forint a 500 miliónov HUF obzulášt' vel'káa,

e) nad 500 miliónov HUF a 1 forint HUF obzvlást' značná. “

47 Zákon č. 2012/C, Trestný zákon Mad’arska (2012. évi C. törvény a Büntető Törvénykönyvről).

48 Všetky prepočty uvedené v štúdii sú platné ku dňu 8. 3. 2020 za pomoci Kalkulačky NBS; Dostupné z: https://www.nbs.sk/sk/statisticke-udaje/kurzovy-listok/kalkulacka

49 Zákon z dňa 20. mája 1971, Priestupkový zákon Pol’ska (Ustawa z dnia 20 maja 1971 r. Kodeks wykroczeń).

50 Zákon zo dňa 6. júna 1997, Trestný zákon Pol’ska (Ustawa z dnia 6 czerwca 1997 r. Kodekskarny). 
(232331,21 €). Tieto hranice však nie sú jediné, na ktoré je potrebné prihliadat'. Na osobitnom úseku daňových deliktov pôsobí daňový trestný zákon ${ }^{51}$, ktorý v nejednom dôležitom ustanovení nadväzuje na činitel’ minimálnej mesačnej mzdy. V čl. 53 ods. 3 tohto zákona zákonodarca rozlišuje medzi daňovými trestnými činmi (fiscal offences / przestępstwa skarbowe) a daňovými priestupkami (fiscal contraventions / wykroczenia skarbowe) za použitia hranice, ktorou je hodnota 5-násobku minimálnej mesačnej mzdy. Z výkladu stricto sensu tak vyplýva, že použitie trestnej represie nastáva až za touto hranicou. ${ }^{52}$ Odvíjajúc sa od minimálnej mesačnej mzdy, ktorá na rok 2020 predstavuje sumu 2600 PLN (604,06 €), hranicou na úseku daňových trestných činov je suma 13000 PLN (3020,31 €). Možnost' najprísnejšieho trestu sa odhodnoty obzvlášt' vel'kej presahujúcej sumu 2600000 PLN $(604061,15 €) .{ }^{53}$

Záverom je tak možné konštatovat', že kategorizácia škôd spôsobených trestným činom sa pohybuje v rozmedzí od 500 PLN (116,17€) pri drobných krádežiach až po 2600000 PLN $(604061,15 €)$ pri daňových trestných činoch. Z právnej úpravy Pol'ska je pritom najdôležitejším zistením skutočnost', že väzba na minimálnu mesačnú mzdu v trestnom zákonodarstve stále nevymrela.

Ukrajinské trestné právo vymedzuje hranicu medzi administratívnou a trestnou zodpovednost'ou, najmä pri drobných krádežiach či sprenevere (podobne ako v Pol’sku), správnym predpisom ${ }^{54}$, pričom za takúto hranicu považuje 0,2 -násobok mesačnej nezdanitel'nej časti základu dane na daňovníka. Poukazovanie na jednotlivé hranice výšok škôd by ani $\mathrm{v}$ tomto prípade nemalo zmysel, avšak z opačných dôvodov ako pri Rakúsku či Nemecku. Ekonomická výkonnost' Ukrajiny a hodnota ukrajinskej hrivny je v porovnaní s oboma krajinami (aj Slovenskom, aj Českom) a ich menami (eurom a českou korunou) prinízka. Príčinou vzatia právnej úpravy Ukrajiny do užšieho výberu krajín je väzba na mesačnú nezdanitel'nú čast' základu dane na daňovníka, ktorá o.i. súvisí so sumou životného minima. Do trestného zákonodarstva tak preniká aj daňový poriadok Ukrajiny, ktorý ustanovuje osobitný výpočet na účely správneho a trestného práva.

51 Zákon z 10. septembra 1999, Daňový trestný zákon Pol’ska (Ustawa z dnia 10 września 1999 r. Kodekskarnyskarbowy).

52 Stricto sensu sa trestná zodpovednost' obmedzuje na zodpovednost' za trestné činy (przestępstwa) a za fiškálne trestné činy (przestępstwa skarbowe). Bližšie pozri NITA, A. a A. ŚWIATŁOWSKI. Administrative versus penal sanctions in polish tax law - the dual system or two systems? In: Beстник ВГУ [online]. Voronež, 2016, s. 196-207 [cit. 20.3. 2020]. Dostupné z: http://www.vestnik.vsu.ru/pdf/ pravo/2016/01/2016-01-22.pdf

53 Súhrnne možno uviest', že podl'a čl. 53 ods. 14, 15 a 16 Zákona z 10. septembra 1999, Daňový trestný zákon Pol'ska (Ustawa z dnia 10 września 1999 r. Kodekskarnyskarbowy), sú typmi škôd nasledujúce:

- bodnotou malou je hodnota, ktorá nepresahuje sumu 200násobku minimálnej mesačnej mzdy;

- bodnotou vel'kou je hodnota, ktorá presahuje sumu 500násobku minimálnej mesačnej mzdy;

- hodnotou obzulást' vel'kou je hodnota, ktorá presahuje sumu 1000násobku minimálnej mesačnej mzdy.

* čl. 53 ods. 3 ustanovuje v štúdii spomínanú osobitnú hranicu 5násobku minimálnej mesačnej mzdy.

54 Čl. 51 Zákona o správnych deliktoch Ukrajiny (Кодекс України про адміністративн і правопорушення). 
Z dôvodu zachovania koncepcie je potrebné dodat', že v normatívnom texte nenachádzame len jedno všeobecné ustanovenie obsahujúce slovné vyjadrenie jednotlivých typov škôd - aplikuje sa mechanizmus poznámok k ustanoveniam, a práve na tomto mieste dostáva priestor zákonná kategorizácia škôd. ${ }^{55}$

\subsection{Zistenia vyplývajúce $\mathrm{z}$ komparácie}

Pre právne poriadky okolitých štátov je príznačná vysoká diverzita $\mathrm{v}$ chápaní zákonnej kategorizácie škôd. Je preto výlučne vecou zákonodarcu ako (a či vôbec) nastaví slovné vyjadrenia jednotlivých typov škôd, pre kol'ko kategórií sa rozhodne, na akých finančných čiastkach budú pozostávat' atd'. Komparatívna metóda tak nebola použitá za účelom presného kopírovania tendencií iných štátov. Ciel’om bolo hladanie prienikov a konštatovanie stále prežívajúcich spôsobov väzby na flexibilné činitele.

Nezanedbatel’ným postrehom je, že trestné zákonodarstvo susedných krajín má evidentný záujem na generálnej prevencii ${ }^{56,57}$, avšak i individuálnej represii vo vzt'ahu k drobným krádežiam či iným nezriedkavým spôsobom páchania majetkovej trestnej činnosti. Tento prvok je možné identifikovat’ najmä pri rakúskej a nemeckej právnej úprave, ktoré umožňujú aplikáciu trestnej represie pri krádeži (alebo inom majetkovom delikte) vo vzt'ahu $\mathrm{k}$ veci, ktorá má čo i len minimálnu hospodársku hodnotu (drobné cukrovinky, fl’aška piva). V rakúskom práve je táto prísnost' zákona ${ }^{58}$ zmiernená privilegovanou skutkovou podstatou trestného činu, v nemeckom práve len procesným aspektom stíhania na návrh. Hranica nepatrnej hodnoty veci závisí - na rozdiel od slovenského, českého, resp. mad’arského a pol’ského právneho poriadku - od rozhodovacej

55 Napríklad trestný čin krádeže podl’a kvalifikovanej skutkovej podstaty v rámci čl. 185 ods. 3 Trestného zákona Ukrajiny nadväzuje na spôsobenie škody značnej; čl. 185 ods. 4 na spôsobenie škody vel'keja čl. 185 ods. 5 na spôsobenie škody obzláš́t vel'kej, pričom finančný obsah týchto pojmov objasňuje poznámka (konkrétne bod 2, 3 a 4) vložená k ustanoveniu čl. 185 tohto zákona. Na základe uvedeného rozlišuje ukrajinské zákonodarstvo v zásade tri stupne škôd, ked’že obdobný mechanizmus je použitý aj pri iných trestných činoch:

- škodou značnou je škoda dosahujúca minimálne sumu 100-až 250-násobku mesačnej nezdanitel’nej časti základu dane na daňovníka;

- škodou vel'kou je škoda presahujúca sumu 250násobku mesačnej nezdanitel’nej časti základu dane na daňovníka;

- škodou obzulás̆t’ vel'kou je škoda presahujúca sumu 600násobku mesačnej nezdanitel’nej časti základu dane na daňovníka.

56 Generálna prevencia spočíva vo výchovnom pôsobení trestu na ostatných členov spoločnosti a uskutočňuje sa prostredníctvom individuálnej prevencie. Bližšie pozri MENCEROVÁ I., L. TOBIÁŠOVÁ, Y. TURAYOVÁ a kol. Trestné právo hmotné: V šeobecná čast'. 2. vyd. Šamorín: Heuréka, 2015, s. 284.

57 Resp. k zohl'adneniu ochrannej a preventívno-represívnej funkcie trestného práva, ktorú podl'a prof. Šámala nemožno oddel'ovat'. Bližšie pozri ŠÁMAL, P. Trestní zákoník a naplňování funkcí a základních zásad trestního práva hmotného. In: Bulletin advokacie, Praha: ČAK, 2009, č. 10, s. 22.

58 Paradoxnou sa javí skutočnost', že z hl’adiska trestných sadzieb je pri porovnaní slovenského, českého a rakúskeho, resp. nemeckého právneho poriadku situácia opačná - najmä rakúsky, ale i nemecký právny poriadok vykazujú nižšiu mieru propunitívnej orientácie. Bližšie BELEŠ, A. Hypertrofia trestných sadzieb v podmienkach Slovenskej republiky. In: Justičná revue, Bratislava, 2018, roč. 70, č. 10, s. 1029-1042. 
praxe a odbornej literatúry, kde je možné identifikovat' nejednotný prístup bez toho, že by vznikali námietky voči nedostatočnej určitosti zákona, teda porušeniu nullum crimen sine lege certa. Z ústavnoprávneho hl'adiska nemožno tento systém represie považovat' za disproporcionálny. Predpokladáme však, že v praxi orgánov aplikácie práva dochádza v týchto krajinách k častému uplatneniu inštitútov zohl'adňujúcich zásadu subsidiarity trestnej represie. ${ }^{59}$ Čo je však dôležité, formálne je ich trestné stíhanie možné.

$\mathrm{Na}$ druhej strane je zrejmá zdržanlivost' v nastavení najprísnejšieho stupňa škody. Ked’že v prvej časti štúdie bolo neraz vyzdvihnuté, že všeobecnú čast' nemožno vnímat' bez súladu s osobitnou čast'ou, je tiež nevyhnutné skúmat' ako na tieto kvantifikanty reagujú konkrétne skutkové podstaty trestných činov, a to s dôrazom na trestné sadzby hroziace za ich naplnenie.

Pre ilustráciu bol vybraný najväčší rozdiel medzi slovenskou a mad’arskou právnou úpravou, t.j. škoda vel'kého rozsahu s poukazom na \125 ods. 1 TZ SR predstavujúca sumu $133000 €$ vs. škoda obzvlást' značná s poukazom na $\int 459$ ods. 6 písm. e) mad’arského trestného zákona predstavujúca sumu 500 mil. HUF, a teda v prepočte spomínaných $1490401,82 €$. Vybraným príkladom je kvalifikovaná skutková podstata trestného činu daňového podvodu ${ }^{60}$ nadväzujúca na uvedený (najvyššî) stupeň škody. Podl’a \277a ods. 3 písm. a) TZ SR sa odňatím slobody na sedem rokov až dvanást' rokov páchatel' potrestá, ak spácha čin uvedený v odseku $1^{61}$ vo vel'kom rozsahu. Podl'a \ 396 ods. 5 písm. a) mad'arského trestného zákona sa odňatím slobody na pät' až desat' rokov páchatel' potrestá, ak sa dopustí daňového podvodu, ktorý spôsobí obzulást' żnačné finančné znevýhodnenie. O širšej represii ustanovenej slovenským zákonodarcom a prinízkom finančnom obsahu škody vel'kého rozsahu tak znova niet pochýb. ${ }^{62}$

Posledným dôležitým bodom je stála existencia pružných činitel’ov v trestnom zákonodarstve. Naviazanie jednotlivých typov škôd na minimálnu mesačnú mzdu využíva v určitom rozsahu Pol'sko. Na mesačnú nezdanitel'nú čast' základu dane na daňovníka zasa nadväzuje Ukrajina. V tomto kontexte je treba tiež spomenút' nevyjasnené (a teda tiež pružné) kritériá nepatrnosti v rakúskom a nemeckom práve.

59 Bližšie pozri TIBITANZLOVÁ, A. a J. MULÁK. Ještě několik poznámek na téma zásady subsidiarity trestní represe. In: Trestnęprávní revue, Praha: C. H. Beck, 2018, roč. 17, č. 5, s. 115-120.

60 Tento typ protiprávneho konania je v Českej republike súčast'ou skutkovej podstaty trestného činu Skrátenia dane, poplatku a podobnej povinnej platby podl’a \240 TZ ČR. Myšlienka prípadu sa dá aplikovat' obdobne s rozdielom, že trestná sadzba v $\int 240$ ods. 3 písm. a) je rovnaká ako v Mad’arsku, tj. 5-10 rokov.

61 Trestný čin daňového podvodu podl'a \277a ods. 1 Trestného zákona: „Kto neoprávnene [...] uplatni nárok na vrátenie dane zpridanej hodnoty alebo spotrebnej dane v úmysle zadovážit' sebe alebo inému neoprávnený prospech, [...]. "

62 Záverom je, že suma $133000 €$ (predstavujúca škoodu vel'kého rozsabu) síce je nominálne nižšia, ale slovenský zákonodarca jej prikladá vyššiu normotvornú silu než mad’arský zákonodarca sume 1490 401,82€ (predstavujúcej škodu obzvláš̉ značnû), a to i napriek tomu, že je nominálne o viac ako $11 \times$ vyššia, resp. následok trestného činu je nominálne o $11 \times$ závažnejší. Uvedené sa pritom dotýka väčšieho množstva prípadov. 


\section{Rozbor finančného obsahu jednotlivých typov škôd}

Účelom tejto časti je rozbor českej Novely (účinnej od 1. 10. 2020) smerom k úpravám \} 1 3 8 \text { ods. } 1 \text { TZ ČR. Sumy sú preto výnimočne ponechané v českých korunách (Kč). } V prvom rade si zasluhuje pozornost' zaujímavý postreh prof.Jelínka ${ }^{63}$ či Dr. Dolenského ${ }^{64}$ o vzt'ahu majetkovej škody a stupňa nebezpečnosti činu pre spoločnost' z konca 80-tych rokov minulého storočia ${ }^{65}$. Obaja autori zdôrazňujú pomer 1:5 medzi jednotlivými typmi škôd, t. j. 1, 5, 20 a 100 tisíc Kčs, pričom tento pomer zostal rovnaký aj pri v tom čase novo-stanovených orientačných peňažných čiastkach ${ }^{66}$, napr. značná škoda 50000 Kčs a škoda velkého rozsahu 250000 Kčs. V súčasnosti sa tento pomer v zásade zmenil na pomer 1:10 (za fikcie úplnej neexistencie škody nikoli malej, ktorá v tom čase nejestvovala), čo je správnym odrazom zmeny rozsahu trestnej činnosti, teda nárastu objemu škôd najmä pri ekonomickej kriminalite.

Ako bolo uvedené, okolité štáty dbajú na generálnu prevenciu vo vzt'ahu k drobným krádežiam či iným nezriedkavým spôsobom páchania majetkovej trestnej činnosti. ${ }^{67}$ Obavou z možného následku sa tak snažia pôsobit' na potenciálnych páchatel’ov tej trestnej činnosti, ktorá je v štatistikách kriminality vždy na popredných miestach. ${ }^{6}$ Tradíciu tohto prístupu je možné identifikovat' v rakúskej a nemeckej právnej úprave. Odborné názory proti dekriminalizácii bagatel’nej kriminality poukazujú jednak na problém jej vecného vymedzenia a jednak na nebezpečenstvo vytvorenia tzv. vákua z hl'adiska generálnej prevencie. ${ }^{69} \mathrm{Aj}$ to tvorí jeden $z$ argumentov, prečo možno Novelu, ktorá ustanovuje zdvojnásobenie škody určujúcej hranicu medzi administratívnou a trestnou zodpovednost'ou, považovat' za spornú.

Domnievame sa tiež, že svojich odporcov nájde aj faktický dopad na prechod vecí z trestných do priestupkových konaní. I ked’ dôvodová správa k Novele ${ }^{70}$ obsahuje záver

63 JELÍNEK, J. Otázky související s majetkovou škodou a typovou nebezpečností činu. In: Socialistická zákonnost. Praha: Ministerstvo spravedlnosti ČSFR, 1988, roč. 36, č. 1, s. 25-37.

64 DOLENSKÝ, A. Pojem, povaha a stupeň nebezpečnosti pro společnost. In: Diferenciace trestni odpovědnosti: Sborník dokumentu a prúspèvkì z kolokvia Čs. nár. skupiny Mez̧in. společ. pro trestní právo AIDP. Praha: Univerzita Karlova, 1983, s. 176.

$65 \mathrm{~V}$ uvedenom období sa ešte stále jednalo len o približné hranice jednotlivých typov škôd - vyplývajúc z materiálneho, resp. materiálno-formálneho chápania trestného činu - stanovené judikatúrou, nie zákonom (až do prijatia novely 1990).

66 Zmena nastala Stanoviskom Najvyššieho súdu ČSSR Plsf 2/87.

67 Otáznym by však bolo skúmanie či takéto nízke nastavenie súm rozhodných pre trestnú zodpovednost' plní svoj odstrašujúci účel.

68 Rozšírenie páchania deliktov totiž súvisí s ich bagatel’nost'ou. KAISER, G. Möglichkeiten der Bekämpfung von Bagatellkriminalität in der Bundesrepublik Deutschland. Zeitschrift für die gesamte Strafrechtswissenschaft, 1978 , roč. 90 , č. 4, s. 877-904.

69 „Mit dem Verzicht auf die Strafbarkeit würde ein generalpräventives Vakuum entstehen [... “" MEIER, B.-D. Bagatellarische Tatbestände. Zeitschrift für die gesamte Strafrechtswissenschaft, 2017, roč. 129, č. 2, s. 433-447. Riešenie spočíva podl'a tohto autora vo vylúčení ukladania trestu odňatia slobody za bagatel'né delikty.

70 Resp. k návrhu novely z novembra 2019, pozri vyššie. 
zo štatisticky podložených údajov, nie je vylúčené ani podcenenie situácie. Zníženie počtu trestných činov bude vysoko pravdepodobne znamenat’ adekvátny nárast počtu priestupkov, a teda pret’aženie správnych orgánov.

I ked' trestné právo rozhodne nemôže byt' prostriedkom verejného nátlaku, výnimočne dávame na zretel' aj postoj verejnosti. Tá je k akýmkol’vek úl'avám trestného zákonodarstva (aj tým potrebným a logickým) vel’mi citlivá. Čarovnú hranicu rozdielu medzi „priestupkovým“ a „trestným“ však vníma ešte o niekol’ko stupňov citlivejšie. ${ }^{71}$

Narážame tak na abstraktné mantinely medzi záujmami uvedenými v predchádzajúcich troch odsekoch, ktorých následkom by bolo rozhodnutie hranicu trestnej zodpovednosti vôbec nenavyšovat', a záujmom na dôslednom odraze ekonomickej reality (prameniaceho z princípu právnej istoty či princípu ultima ratio v normotvornej činnosti). Určitým kompromisom by preto mohol byt' nárast zohl’adňujúci iba mieru inflácie, t.j. $7000 \mathrm{Kč}^{72}$, prípadne 7500 Kč. Tiež sa prihovárame k námetu vysvetlenému v d’alšej alinei, t. j. k doplneniu pojmu „postihnutý“ do vybraných skutkových podstát trestných činov.

Inšpiráciou na zmiernenie dopadov navýšenia škody nikoli nepatrnej sa zdá byt' práve slovenská právna úprava. Ustanovenie $\ 212$ ods. 1 písm. g) TZ SR deklaruje, že ,kto si prisvoji cudziu vec tým, že sa jej zmocní a bol za obdobný čin v predchádzajúcich dvanástich mesiacoch postihnutý, potrestá sa odñatím slobody až na dva roky. "Rozmenené na drobné, ak bol páchatel' v predchádzajúcich dvanástich mesiacoch postihnutý za priestupok proti majetku ${ }^{73}$, a v tomto období spácha obdobný čin ${ }^{74}$, tento čin je stíhatel'ný ako trestný bez ohladu na výšku škody. Zavedením pojmu „postihnutý“ tak zákonodarca efektívne chráni spoločnost' pred prípadmi, kedy by dochádzalo k opakovanému prisvojeniu si cudzej veci tým istým páchatel’om. TZ ČR však rovnakú konštrukciu nepozná, a obdobne ju používa len vo vzt'ahu k osobe odsúdenej alebo potrestanej $j^{75}$ (\$ 205 ods. 2 TZ ČR ${ }^{76}$ ). Je tiež potrebné

71 Jedno z českých spravodajských médii (TN.cz) vytvorilo anketu s otázkou: „Mèla by se zmènit hranice škody, prì niž jde u气̌ o trestný čn? "Až $92 \%$ hlasujúcich (1452 z celkového počtu 1580) zastáva negatívny postoj, t.j. NIE. Úleva pro zloděje?! Politici chtějí změnit hranici, kdy jde o trestný čin. TN.cz [online]. [cit. 21. 3. 2020]. Dostupné z: https://tn.nova.cz/clanek/misto-5-tisic-10-politici-chteji-zvysit-hranici-kdy-jde-o-trestny-cin.html

72 Inflácia sa za obdobie 2002-2019 zvýšila o cca 39 \%. Údaje vyplývajú z priemernej ročnej miery inflácie pre roky 2002-2019 každoročne zverejnenou ČSÚ. Inflace - druhy, definice, tabulky. Ceskéy statistický úrad [online]. [cit. 21. 3. 2020]. Dostupné z: https://www.czso.cz/csu/czso/mira_inflace; S prepojením na tieto údaje pracuje aj Kalkulačka inflace. peniže.cz [online]. [cit. 21.3. 2020]. Dostupné z: https://www. penize.cz/kalkulacky/znehodnoceni-koruny-inflace

73 Ust. \50 ods. 1 zákona č. 372/1990 Zb. o priestupkoch: „Priestupku sa dopusti ten, keto úmyselne spôsobí škodu na cudzom majetku krádežou, spreneverou, podvodom alebo zničením alebo poškodením veci z takého majetku, alebo sa o takéto konanie pokuisi."

74 K výkladu „postihnutý za obdobný čin“ pri trestnom čine krádeže pozri Rozsudok Najvyššieho súdu SR zo dňa 28. apríla 2016, sp. zn. 7Sžo/104/2014.

$75 \mathrm{~K}$ výkladu pojmov „odsúdený“ a „potrestaný“, t.j. k recidíve ako podmienke trestnej zodpovednosti pozri ŠÁMAL, P. a kol. Trestni zákoník. Komentár. 2. vyd. Praha: C. H. Beck, 2012, s. 1994-1998.

76 Ust. \205 ods. 2 TZ ČR: „Kdo si prísvoji cizi věc tím, že seji żmocní, a byl za takový čin v poslednich trech letech odsouz̨en nebo potrestán, bude potrestán odnètím svobody na šest mèsici až trí léta." 
dodat', že v dôsledku zvyšovania hranice trestnej zodpovednosti považujeme za vhodnejšie rozšírenie časového obdobia, na ktoré sa vzt'ahuje možnost' vyvodenia trestnej zodpovednosti na časové obdobie korešpondujúce s \205 ods. 2 TZ ČR, t. j. na tri roky. $\mathrm{Na}$ zváženie je aj častejšie využitie tohto pojmu v českom trestnom zákonodarstve.

V prípade rozhodnutia nenavýšit' škodu nikoli nepatrnú by bolo v aplikačnej praxi nevyhnutné apelovat' na primárne preventívne pôsobenie takejto právnej úpravy, a tým aj detailné zváženie všetkých okolností prípadu so zretel’om na uplatnenie princípu ultima ratio $\mathrm{v}$ jeho aplikačnej podobe ${ }^{77}$ - v súlade $\mathrm{s}$ bodom 33 nálezu Ústavního soudu ČR zo dňa 26. 5. 2020, sp. zn. Pl. ÚS 46/18 a právnym názorom vyjadreným v spoločnom odlišnom stanovisku sudkyne Kateřiny Šimáčkové a sudcu Pavla Šámala (bližšie pozri kapitolu 1 tejto štúdie). Takéto riešenie má ale v českých (a obdobne aj slovenských) podmienkach dve roviny - pozitívnu a negatívnu. Tá prvá, pozitívna, zabráni formálnym prekážkam trestného stíhania (nedostatočná výška škody) pri činoch, ktorých spôsob spáchania vykazuje závažnejší stupeň nebezpečnosti pre spoločnost' (napr. pokračovací trestný čin krádeže $\mathrm{e}^{78}$ ). Tiež sa môže naplnit' predpoklad ochrannej a preventívno-represívnej funkcie trestného práva. Druhá rovina ale počíta so situáciou, ked' by tento predpoklad naplnený nebol, t. j. faktický počet drobných krádeží by v prípade navýšenia/nenavýšenia škody nikoli nepatrnej ani neklesal, ani nestúpal. Princíp právnej istoty by tak ustupoval zbytočne. Zákonodarca síce vytvoril podmienky na uplatňovanie princípu ultima ratio $\mathrm{v}$ jeho aplikačnej podobe, avšak treba uznat', že ten má byt' v prvom rade východiskom pri normotvornej činnosti, čo platí dvojnásobne pri mantineloch daných tak pevne, ako je tomu v prípade v \ 138 ods. 1 TZ ČR. Ako ukázal aj sám nález Ústavního soudu ČR zo dňa 26. 5. 2020, sp. zn. Pl. ÚS 46/18, prístupy $\mathrm{k}$ použitiu korektívov sú rôzne. Je preto otázne, $\mathrm{v}$ akom percente prípadov by zo strany orgánov aplikácie práva došlo k reálnemu uprednostneniu materiálnych kritérií nad kritériami formálnymi. ${ }^{79}$ Napokon, takéto riešenie by nesplnilo účel obmedzit' zat'ažovanie

77 Tzv. hmotnoprávny korektív podla $\int 12$ ods. 2 TZ ČR a tzv. procesný korektív podla $\ 172$ ods. 2 písm. c) TRR̆. TZ SR neustanovuje úpravu princípu ultima ratio, tak ako $₫ 12$ ods. 2 TZ ČR, obdobou je jeho pripustenie vo sfére tzv. materiálnej protiprávnosti trestného činu, teda pri posudzovaní závažnosti prečinov v rámci $\ 10$ ods. 2 TZ SR (materiálny korektív). Česká právna úprava - na rozdiel od slovenskej - obsahuje aj procesný korektív v zmysle $\ 172$ ods. 2 písm. c) TRŘ, ktorého podstatou je neúčelnost' stíhania páchatel'a. Bližšie pozri MULÁK, J. Základni zásady trestního ř̌zení a právo na spravedlivý proces. Praha: Leges, 2019, s. 140 a nasl.

78 Pozri aj zjednocujúce Stanovisko trestnoprávneho kolégia Najvyššieho súdu Slovenskej republiky zo dňa 16. apríla 2018, Tpj 57/2017, na základe ktorého sa formulácia „trestnost’ všetkých čiastkových útokov sa posudzuje ako jeden trestný čin“ podl’a \122 ods. 10 TZ SR, interpretuje tak, že výška spôsobenej škody alebo získaného prospechu sa pri jednotlivých čiastkových útokoch na účel určenia právnej kvalifikácie spočítava.

79 Pozri napríklad: SZABOVÁ, E. a M. DESET. Princíp ultima ratio a jeho uplatnenie v rámci majetkových trestných činov. In: Acta Facultatis Iuridicae Universitatis Comenianae, roč. 36, mimoriadne č́slo, 2017, s. 190-200 [online]. [cit. 22. 3. 2020]. Dostupné z: https://afi.flaw.uniba.sk/index.php/AFI/issue/ view/48/46 
OČTK a súdov bagatel'nými previneniami. Ako rozumnejšie sa nám preto javí zvýšenie hranice trestnej zodpovednosti so súčasným inkorporovaním pojmu „postihnutýc do TZ ČR tak, ako bolo uvedené vyššie.

Na správne vyjadrenie potrieb trestného zákonodarstva je poznanie (aspoň približného) rozsahu škôd spôsobovaných trestnou činnost'ou určujúce. K hodnoteniu finančného obsahu ostatných štyroch typov bude preto nápomocný výpočet priemernej škody spôsobenej hospodárskou a majetkovou kriminalitou za ostatných 10 rokov. Do úvahy boli vzaté len údaje vykázané v tomto rámci, nie v širšom poňatí „celkovej kriminality“, a to z prostého dôvodu. Celková výška škôd by v pomere k všetkým zisteným trestným činom spôsobila faktické skreslenie priemeru. ${ }^{80}$

Tabul'ka č. 3: Priemerná škoda spôsobená hospodárskou a majetkovou kriminalitou za posledných 10 rokov v Českej republike

\begin{tabular}{|c|c|c|c|c|c|c|c|}
\hline & \multicolumn{3}{|c|}{ Hospodárska kriminalita } & \multicolumn{3}{|c|}{ Majetková kriminalita } & \multirow{2}{*}{$\begin{array}{l}\text { SPOLU } \\
\text { Priemerná } \\
\text { škoda }^{83}\end{array}$} \\
\hline & Zistené & $\begin{array}{c}\text { Škoda } \\
\text { (v tis. Kč) }\end{array}$ & $\begin{array}{c}\text { Priemerná } \\
\text { škoda }^{81}\end{array}$ & Zistené & $\begin{array}{c}\text { Škoda } \\
\text { (v tis. Kč) }\end{array}$ & $\begin{array}{c}\text { Priemerná } \\
\text { škoda }^{82}\end{array}$ & \\
\hline 2010 & 28371 & 14153834 & 498883 & 203717 & 8380595 & 41138 & 97094 \\
\hline 2011 & 28216 & 13899515 & 492611 & 203675 & 8485163 & 41660 & 96531 \\
\hline 2012 & 27633 & 24135981 & 873448 & 194970 & 7553775 & 38734 & 142360 \\
\hline 2013 & 30376 & 19587078 & 644821 & 209351 & 8008155 & 38252 & 115111 \\
\hline 2014 & 30731 & 20850300 & 678478 & 173611 & 6554129 & 37752 & 134111 \\
\hline 2015 & 30616 & 20250981 & 661451 & 139092 & 5377511 & 38662 & 151015 \\
\hline 2016 & 28306 & 18779626 & 663450 & 118082 & 4456627 & 37742 & 158731 \\
\hline 2017 & 26294 & 13677456 & 520174 & 108497 & 4126400 & 38032 & 132084 \\
\hline 2018 & 24837 & 10639767 & 428384 & 98670 & 4689858 & 47531 & 124119 \\
\hline 2019 & 24589 & 17322427 & 704479 & 102136 & 4931682 & 48285 & 175609 \\
\hline 2010-2019 & & & 616618 & & & 40779 & 132677 \\
\hline
\end{tabular}

Zdroj: Statistické přehledy kriminality v České republice. Policie ČR [online]. [cit. 22. 3. 2020]. Dostupné z: http://www.policie.cz/statistiky-kriminalita.aspx

80 Spôsobenie majetkovej škody je pri trestných činoch zaradených k inej, než majetkovej alebo hospodárskej kriminalite (napr. násilnej, mravnostnej či ostatnej) len ich zriedkavým a častokrát bagatel'ným následkom.

81 Priemerná škoda (v Kč) spôsobená hospodárskou kriminalitou = Škoda (v tis. Kč) spôsobená hospodárskou kriminalitou / počet zistených TČ spadajúcich do rámca hospodárskej kriminality.

82 Priemerná škoda (v Kč) spôsobená majetkovou kriminalitou = Škoda (v tis. Kč) spôsobená majetkovou kriminalitou / počet zistených TČ spadajúcich do rámca majetkovej kriminality.

83 Priemerná škoda (v Kč) spôsobená hospodárskou a majetkovou kriminalitou celkovo = Škoda (v tis. Kč) spôsobená hospodárskymi a majetkovými kriminalitou celkovo / počet zistených TČ spadajúcich do rámca majetkovej kriminality celkovo. 
Z Tabul'ky č. 3 vyplýva, že priemerná škoda spôsobená hospodárskou kriminalitou za ostatných 10 rokov tvorí sumu 616618 Kč, škoda spôsobená kriminalitou majetkovou v priemere sumu $40779 \mathrm{Kč}$, a priemerná škoda spôsobená hospodárskymi a majetkovými trestnými činmi v súhrne celkovo 132677 Kč. Optikou prof. Solnařa však „,pro presné studium zločinnosti platí požadavek, že nestač zločinnost mériti, je tréba ji váżiti. To bývá na zákeladè poubé kriminálni statistiky možné jen žrídka a mèrou omeẓenou. " $84 \mathrm{Na}$ uvedené dáta je tak potrebné nazerat's rezervou.

Uvedené však nič nemení na fakte, že nastavenie zákonnej kategorizácie škôd pred Novelou skutočne nezodpovedalo požiadavkám. Nielen z dôvodu potreby reagovat' na zmeny ekonomickej reality, ale aj z dôvodu kriminálnej reality samej. Rozsah škôd spôsobených trestnou činnost’ou je pri hospodárskych trestných činoch enormný.

Ako vyplynulo zo záverov prvej časti štúdie, hranica škody nikoli malej v pomere k škode nikoli nepatrnej je len d’alšou potenciálnou hranicou medzi priestupkom a trestnoprávnym postihom. Zákonodarca ju využíva ako hranicu trestnej zodpovednosti najmä pri hospodárskych trestných činoch, ktorých povaha predznačuje vyšší rozsah spôsobenej škody napríklad TČ úverového podvodu ${ }^{85}$, kde priemerná škoda ${ }^{86}$ za ostatných 10 rokov činí 363396 Kč alebo TČ poškodzovania veritel'a ${ }^{87}$ s priemernou škodou až 1982417 Kč. Hranicu 50000 Kč, korešpondujúcu s Novelou, považujeme za adekvátnu, plniacu tiež úlohu generálnej prevencie.

Škoda vétši predstavuje podl’a Novely sumu 100000 Kč a škoda značná sumu 1000000 Kč. Samozrejme, škoda vétši tvorí v niektorých prípadoch tiež hranicu trestnej zodpovednosti, avšak ani v tomto ohlade ju nemožno považovat' za privysokú. Napríklad priemerná škoda za ostatných 10 rokov sa pri TČ skrátenia dane, poplatku a podobnej povinnej platby $^{88}$ vyšplhala až na úroveň 5712355 Kč. V právnom stave pred Novelou pritom škoda nad $5000000 \mathrm{Kč} \mathrm{spadala} \mathrm{pod} \mathrm{najprísnejší} \mathrm{kvantifikant,} \mathrm{škodu} \mathrm{velkého} \mathrm{rozsahu.} \mathrm{Jav}$ sankcionovania „priemeru“, teda trestných činov s priemernou vzniknutou škodou, čiže priemernou spoločenskou závažnost’ou, najprísnejšími trestnými sadzbami by v trestnom práve nemal nachádzat' svoje opodstatnenie. Nárast škody velkého rozsahu na úroveň 10000000 Kč preto považujeme za správny.

Na tomto mieste opakujeme už raz deklarované konštatovanie, že zákonná kategorizácia škôd pred Novelou nezodpovedala požiadavkám trestného práva, a to nielen z dôvodu potreby reagovat' na zmeny ekonomickej reality, ale aj z dôvodu kriminálnej reality samej. Stanovenie

\footnotetext{
84 SOLNAŘ, V. Zločinnost v zemích českých v létech 1914-1922. Praha: Nákladem knihovny sborníku věd právních a státních, 1931 , s. 7.

85 Ust. \ 211 TZ ČR.

86 Pri jej výpočte bola použitá rovnaká systematika ako pri výpočte priemernej škody hospodárskou alebo majetkovou kriminality.

87 Ust. \ 222 TZ ČR.

88 Ust. \ 240 TZ ČR.
} 
hraníc jednotlivých typov škôd spočívalo (a stále spočíva) na pevných peňažných čiastkach, ktoré v trestných zákonoch pôsobia vždy dlhšie obdobie, možno jednu dekádu, možno dlhšie. So zdvojnásobením súm určujúcich jednotlivé hranice výšok škôd, okrem škody nikoli malej, sa preto možno stotožnit'. To znamená, že sme prišli takmer k podobnému záveru ako skupina poslancov, len s iným odôvodnením. Do budúcna ale poukazujeme na potrebu zvážit' skúsenosti zo zahraničnej právnej úpravy a následky na pomer počtu trestných činov a priestupkov. Odlišnost' odôvodnenia spočíva v premise, že pre trestné zákonodarstvo by mala byt' určujúca najmä miera inflácie (nie priemernej či minimálnej mzdy), čo bude ešte využité v d’alšom texte.

\section{Suma životného minima - inšpirácia pro futuro?}

O snahe maximalizovat' pružnost ${ }^{89}$ trestnej legislatívy niet pochýb. Uvedené platí o to viac, ak je reč o zákonnej kategorizácii škôd, ktorá je často rozhodná bud’ pre samotnú trestnost’ činu, alebo jeho právnu kvalifikáciu. Myšlienka nadviazania škody na jeden z flexibilných ekonomických inštitútov tak má svoj potenciál, a to i napriek tomu, že sa v histórii oboch krajín neujala.

Z uvedenej komparatívnej analýzy vyplýva, že z trestných zákonov okolitých krajín nevymizlo ani nadviazanie na flexibilné inštitúty. V tejto súvislosti je potrebné skúmat', či je prinavrátenie určitej formy pružnosti možné aj v našich podmienkach. Samozrejme, za rešpektovania právnych a ekonomických požiadaviek.

Nevhodnost' použitia minimálnej mzdy na účely trestného zákonodarstva bola objasnená hned' úvodom. Nekompatibilita minimálnej mzdy s potrebami trestného práva však nebola daná vždy. Na Slovensku sa istý čas minimálna mzda ustanovovala na zákonnej úrovni ${ }^{90}$, nerástla radikálnym tempom a bola užšie spätá so sumou životného minima. Napríklad dôvodová správa k zákonu č. 56/1999 Z. z. ${ }^{11}$, ktorým sa novelizoval vtedajší zákon č. 90/1996 Z. z. o minimálnej mzde s účinnost'ou od 1. apríla 1999, uvádza, že reaguje na úpravu životného minima zvýšením minimálnej mzdy o $20 \%{ }^{92} \mathrm{~V}$ čase písania tejto štúdie by ale takáto argumentácia predstavovala nárast o priepastných 176 \% , ked’že rozdiel medzi sumou životného minima a minimálnej mzdy sa podstatne

89 Pružnost'ou trestnej legislatívy majú autori na mysli požiadavku, aby trestnoprávne normy boli schopné pružne reagovat' na zmeny vonkajšieho prostredia, t. j. v našom prípade na zmeny ekonomickej reality.

90 Minimálna mzda, a tým aj hranice jednotlivých typov škôd, bola na zákonnej úrovni ustanovená v období rokov 1996 až 1999, čím nedochádzalo k porušeniu medzinárodnoprávnej garancie nullum crimen sine lege scripta. BELEŠ, A. a HANGÁČOVÁ, N. Vývoj právnej úpravy hranice minimálnej škody. In: Notitia Indiciales Academie Collegii Aedilium in Bratislava, Bratislava: Akadémia Policajného zboru v Bratislave, 2019, roč. 5 , č. 1 , s. 5 .

91 Dôvodová správa k zákonu č. 56/1999 Z. z. Národná rada SR [online]. [cit. 23. 3. 2020]. Dostupné z: https://www.nrsr.sk/dl/Browser/Document?documentId=162201

$92 \mathrm{~V}$ deklarovanom období suma životného minima predstavovala $3000 \mathrm{Sk}$ a suma minimálnej mzdy $3600 \mathrm{Sk}$. 
zvýšil. $^{93}$ Z porovnania medziročného rastu sumy životného minima a minimálnej mzdy vyplýva výrazný rozdiel. ${ }^{94}$

Právnym základom sumy životného minima ${ }^{95}$ je v slovenskom právnom poriadku zákon č. 601/2003 Z. z. o životnom minime (d’alej len ako „ZoŽM“"). Hlavným rozdielom medzi týmto inštitútom u nás a v Českej republike je najmä obligatórnost' v každoročnom prehodnocovaní jeho výšky a sila rozhodovacej právomoci daná jednotlivým orgánom.

Podl’a $\int 5$ ods. 1 ZoŽM sa suma životného minima upraví vždy k 1 . júlu bežného kalendárneho roka, ak v odseku $6^{96}$ nie je ustanovené inak. Zákonodarca pritom ustanovuje exaktný vzorec ${ }^{97}$ založený na koeficiente rastu čistých peňažných príjmov na osobu alebo koeficiente rastu životných nákladov nízkopríjmových domácností. Podla tohto vzorca sa musí postupovat' pri každoročnom posudzovaní výšky sumy životného minima. Úpravu súm má v kompetencii Ministerstvo práce, sociálnych vecí a rodiny SR, ktoré v záverečnom procese vydá opatrenie s novou sumou životného minima. Tá je d’alej inkorporovaná do samotného normatívneho znenia ZoŽM, čím zákonodarca tieto sumy schvaluje, a stavia ich do výrazne intenzívnejšej pozície z hl’adiska právnej sily.

Česká republika stavia $\mathrm{v}$ tomto smere na princípe fakultatívnosti. Vychádzajúc z \ 9 ods. 1 zákona č. 110/2006 Sb. o životnom a existenčnom minime môže sumu životného minima zvýšit' vláda, a to nariadením v pravidelnom termíne od 1. januára, prípadne $\mathrm{v}$ mimoriadnom termíne. ${ }^{98}$ Zákonodarca pritom v tomto odseku ustanovuje aj určitý vzorec a podmienky, za ktorých k zvýšeniu sumy môže dôjst', avšak tieto sú koncipované omnoho benevolentnejšie, čím vláde dávajú pomerne vysokú mieru rozhodovacej právomoci. Faktickým dôsledkom je, že suma životného minima nebola od roku 2012 do 1. apríla 2020 vôbec zvyšovaná.

$93 \mathrm{~V}$ čase písania tejto štúdie suma životného minima predstavuje 210,20€ a suma minimálnej mzdy $580 €$.

94 Aj ked' v hlavnom texte štúdie ide o príklad výraznejšieho rastu minimálnej mzdy ako životného minima na Slovensku, jav postupného odlišovania výšky minimálnej mzdy od výšky sumy životného minima možno demonštrovat' i na grafe spracovanom Výskumným ústavom práce a sociálnych vecí Českej republiky. Z grafu je zrejmé, že prelom nastal na území ČR taktiež po roku 1999, ked’ boli sumy ešte na cca rovnakej úrovni. Po tomto roku sa nožnice rozdielov začali roztvárat' smerom k dnešnému radikálnemu rozdielu. Bližšie pozri Vývoj částek životního minima, průměrné a minimální mzdy. Výzkeumný ústav práce a sociálních véci [online]. [cit. 23. 3. 2020]. Dostupné z: https://www.vupsv.cz/ download/7-vyvoj-castek-zivotniho-minima-prumerne-a-minimalni-mzdy/

95 K sume životného minima v sociálnej politike pozri KREBS, V., a kol. Sociálna politika. 5. prepracované a aktualizované vyd. Praha: Wolters Kluwer ČR, 2010, s. 544.

96 Ust. $\int 5$ ods. 6 Zákona č. 601/2003 Z. z. o životnom minime: „Sumy životného minima sa k. 1. júlu bežného kalendárneho roka neupravia, ak sa koeficient, ktorým by sa podla odseku 2 upravili sumy životnébo minima, rovná jednej alebo je nið̌ši ako jedna."

97 Ust. \5 ods. 2 zákona č. 601/2003 Z. z. o životnom minime.

98 Ust. $\int 9$ ods. 2 zákona č. 110/2006 Sb. o životnom a existenčnom minime. 
Na tomto mieste si zaslúži pozornost' nález Ústavního soudu ČR zo dňa 23. júla 2013, sp. zn. Pl. ÚS 13/1299. Z viacerých častí tohto nálezu vyplýva záver, že existencia podzákonného predpisu $\mathrm{v}$ trestnom práve nie je úplne vylúčená, ak by bola jeho úprava pod kontrolou zákonodarcu. Rovnako ako pri minimálnej mzde, tak i pri úprave sumy životného minima v Českej republike je zrejmá moc exekutívy, ktorej odrazom je vydanie vládneho nariadenia. Ked' sa však pozrieme na úpravu súm životného minima v slovenskom právnom poriadku, možno uzavriet', že jej korekcie sú (pod vplyvom nutnosti dodržiavat' ustanovený vzorec) pod kontrolou zákonodarcu. Na otázku súladu so zásadou nullum crimen sine lege certa, odpovieme slovami sudcu Musila „domnivám se, že z blediska právni jistoty občanu, predvídatelnosti práva a navíc z blediska jeho dostupnosti zvolil zákonodárce cestu velmi komfortni a plnè vyhovujici podminkám právního státu. " 100 Vo svojom odlišnom stanovisku tiež okrajovo spomenul kategorizáciu škôd spôsobených trestným činom, ked’ je podla neho možné ich kvantifikáciu v porovnaní s posudzovanou problematikou drogových deliktov určit' jednoduchšie. K uvedenému je však potrebné dodat', že škodu detailnejšie neposudzoval, resp. škoda a dôraz na princíp právnej istoty ešte nikdy neboli predmetom detailného posúdenia ústavným súdnictvom. Tiež, v časoch vyradenia minimálnej mzdy z trestného zákonodarstva, vládne nariadenie skutočne nespĺňalo požadované kritériá.

Suma životného minima je tak možnost'ou, ktorá by mohla byt', zdá sa, pre slovenské trestné právo vhodným riešením. Z dôvodu odlišného prístupu českého zákonodarcu by však v jeho rámci nebol tento inštitút vyhovujúci. $\mathrm{V}$ d’alších riadkoch sa preto zameriame na výlučný rozbor nami stanoveného (potenciálneho) námetu ustanovenia \125 ods. 1 TZ SR: „Škodou malou sa rozumie škoda dosahujúca najmenej 1,5-násobok sumy životného minima pre jednu plnoletú fyzickú osobu podl'a osobitného predpisu platnej k 1. januáru prísluśnébo kalendárneho roka. Škodou vä̌̌sou sa rozumie suma dosabujúca najmenej pätnást’násobok takej sumy životnébo minima. Škodou značnou sa rozumie suma dosabujúca najmenej stopät'desiatnásobok takej sumy životného minima. Škodou vel'kébo rozsahu sa rozumie suma dosabujúca najmenej tisícpät'stonásobok takej sumy životnébo minima. Tieto bl'adiská sa použijú rovnako na určenie výšky prospechu, hodnoty veci a rozsabu činu. "

K 1. januáru 2020 tvorila podl’a \ 2 písm. a) ZoŽM suma životného minima pre jednu plnoletú fyzickú osobu sumu v hodnote 210,20€. Zákonná kategorizácia škôd by tak na účely TZ SR s účinnost'ou od 1. januára 2020 mala nasledujúcu štruktúru: škoda malá by predstavovala sumu vo výške 315,30 €, škoda väršia sumu vo výške $3153 €$, škoda značná sumu vo výške $31530 €$, a škoda vel'kého rozsahu sumu vo výške $315300 €$. Na tomto mieste pripomíname poslednú kapitolu prvej časti štúdie. Záverom bolo deklarované,

99 Navrhovatel' sa tu domáhal zrušenia ustanovenia \ 289 ods. 2 TZ ČR pre rozpor s čl. 39 Listiny, pričom meritum veci spočívalo v posudzovaní pojmu množstvo väčsie než malé u omamných látok, psychotropných látok, prípravkov ich obsahujúcich a jedov, ktoré bolo stanovené nariadením vlády, a malo tvorit’ hranicu medzi administratívnou a trestnou zodpovednost'ou v rámci vybraných drogových deliktov.

100 Bod 11 odlišného stanoviska Jána Musila k nálezu Ústavního soudu ČR zo dňa 23. júla 2013, sp. zn. Pl. ÚS $13 / 12$. 
že slovenský zákonodarca by mal pod vplyvom inflácie navýšit' škodu vel'kého rozsahu, v súčasnosti charakterizovanú sumou $133000 €$, aspoň na sumu $177274 €$. Z dôvodu

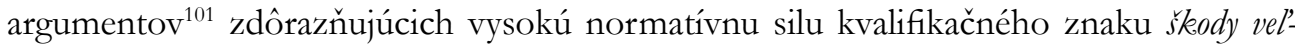
kého rozsahu v slovenskom zákonodarstve však táto zmena nebola považovaná za dostačujúcu. Apelovali sme tak na potrebu adekvátnej reakcie, ktorou by bolo radikálnejšie navýšenie. Námet navýšenia na $315300 €$ plní aj tento záväzok.

Z dôvodu záujmu na riadnom vysvetlení zmien ekonomickej reality s dôrazom na meniacu sa mieru inflácie bol zostavený Graf č. 1. Ten odráža predpoklad naviazania zákonnej kategorizácie škôd na sumu životného minima už od roku 2006. K 1. januáru 2006 bola suma životného minima pre jednu plnoletú fyzickú osobu podl’a $\int 2$ písm. a) ZoŽM ustanovená vo výške 4730 Sk, čo v prepočte činí 157,01 €. Ked’že škoda malá na účely Trestného zákona (podl'a nášho námetu) tvorí 1,5-násobok tejto sumy, tak v roku 2006 by sa podl'a vzorca 1,5 × 157,01 vyšplhala na sumu (zaokrúhlene) 235,50€. Peňažnú čiastku, ktorá bola podl'a našej fikcie platná a účinná v roku 2006 (v prepočte na eurá) sme následne podrobili inflácii ${ }^{102}$. Výsledkom je, že reálna hodnota sumy 235,50€ v roku 2006 je pod

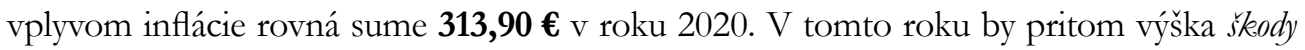
malej na účely TZ SR - podl'a navrhovaného mechanizmu výpočtu - tvorila sumu 315,30 €.

Graf č. 1: Fikcia právnej úpravy. Predpoklad výšky škody malej podl’a vzorca Škoda malá = 1,5násobok sumy životného minima platného $\mathrm{k} 1$. januáru príslušného kalendárneho roka („SŽM“) vs. Vplyv inflácie na čiastku 235,50€ (ktorá tvorila v roku 2006 sumu životného minima) v rokoch 2006-2020.

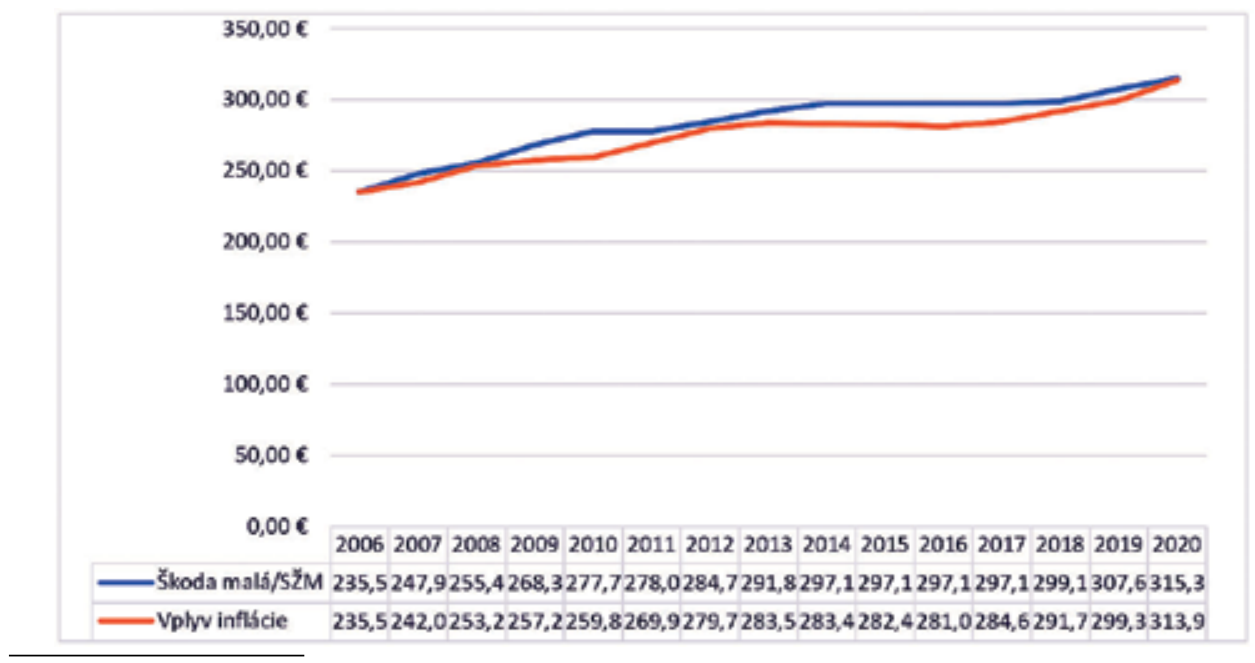

101 Medzi také boli zaradené, in concreto: (i) normatívna sila kvalifikačného znaku škody vel'kého rozsahu; (ii) rastúci rozsah škôd spôsobených trestným činom; (iii) vyvijajúca sa kúpna sila peňazí, resp. inflácia. Bližšie pozri ČENTÉŠ, J., A. BELEŠ a J. ČIPKOVÁ. Kategorizácia škôd spôsobených trestným činom (I. čast'). In: Časopis pro právni vědu a praxi, Brno: Právnická fakulta Masarykovy univerzity, 2020, roč. 28, č. 2, s. 225-246.

102 Výpočet bol vytvorený ku dňu 23. 3. 2020 za pomoci Inflačnej kalkulačky. Inštitút pre ekonomické a sociálne reformy [online]. Dostupné z: http://www.ineko.sk/kalk.html 
$\mathrm{Na}$ základe vyššie uvedeného možno uzavriet', že aj o takmer 15 rokov neskôr by sa krivka inflačného vývoja značne približovala krivke znázorňujúcej postupný nárast škody malej podla navrhovaného mechanizmu. Jednotlivé sumy pritom z roka na rok nerastú rapídne, čím by sa predchádzalo skokovému nárastu.

Opomenút' nemožno ani fakt, že v rokoch 2014 až 2016 dochádzalo k záporným hodnotám, t. j. Slovensko bolo vd'aka ekonomickej kríze v deflácii. ${ }^{103}$ Začiatkom roka 2017 sa inflácia vrátila. Z grafického znázornenia je zrejmé, že v rokoch 2014 až 2017 bola suma životného minima zmrazená, čo vyplývalo z aplikácie $\int 5$ ods. 6 ZoŽM. Deklarovat' tak možno splnenie reakcie na prípadnú defláciu v budúcom období.

Záverom si nedovolíme vynechat' ani nevýhody naviazania na pružný činitel', ktorý môže $\mathrm{v}$ aplikačnej praxi spôsobovat' problémy spočívajúce napríklad v páchaní dlhodobej pokračovacej trestnej činnosti, kde je potrebné prihliadat’ i k zmenám základu, ak k ním v priebehu pokračovania trestnej činnosti došlo. ${ }^{104}$ Nel’ahkým je aj skúmanie, kedy presne došlo k spôsobeniu škodlivého následku, v akom rozsahu, a aký vplyv má toto časové hladisko, a každoročná zmena výšky škody malej na trestnú zodpovednost' páchatel'a, a to najmä v prípade spôsobenia tzv. hraničných škôd. Práca orgánov činných v trestnom konaní a súdov by tak touto zmenou ul'ahčená nebola, no jedným dychom dodávame, že najjednoduchšie riešenia sú len zriedka tými najsprávnejšími.

\section{Intertemporálne ustanovenie}

Predmetná Novela už prešla posúdením finančného obsahu jednotlivých typov škôd. Tiež bolo zistené, že prinavrátenie určitej formy pružnosti je možné, avšak vo vzt'ahu k sume životného minima len na území Slovenskej republiky. Legislatívnou nástrahou, na ktorú sa pri koncipovaní Novely mohlo zabudnút', a mohlo by sa tak stat' aj pri potenciálnom (zatial' stále neexistujúcom) návrhu slovenského zákonodarcu, je prípadná absencia intertemporálneho ustanovenia súvisiaceho s dekriminalizáciou.

Novela sa v tomto smere obmedzila len na jedno prechodné ustanovenie. To sa týka ustanovenia vecnej príslušnosti $\mathrm{v}$ konaniach začatých pred dňom nadobudnutia účinnosti zákona. ${ }^{105}$ Otázkou zostáva, či by pri tak skokovom náraste súm určujúcich jednotlivé hranice výšok škôd nemal brat' zákonodarca na zretel’ ukončenie, resp. skrátenie výkonu trestov za činy, ktoré by bud' (po nadobudnutí účinnosti zákona) už neboli trestným činom, alebo by boli posudzované ako činy miernejšie trestné.

103 Vývoj inflácie v Slovenskej republike v rokoch 2013 až 2017. Datawrapper [online]. [cit. 21. 3. 2020]. Dostupné z: https://app.datawrapper.de/_/U1XaJ

104 TERYNGEL, J. K novele trestního zákona. In: Právo a zákonnost. Praha: Ministerstvo spravedlnosti ČR, 1990 , č. 9, s. 515-524.

105 Čl. II Novely: „V ř́zenich zahájených préde dnem nabytí účnnosti tohoto zákona se pro účely stanoveni věcné prísluš-

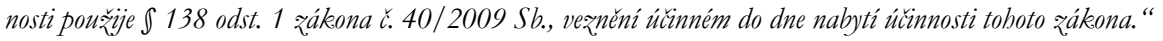


Inšpiráciou nám môže byt' práve novela 1990, ktorá zákonnú kategorizáciu škôd sama zaviedla. Netreba však zabúdat' na obdobie, v akom bola prijatá. Jej obšírne dekriminalizačné a depenalizačné opatrenia ${ }^{106}$ priniesli mnohé z reakcií na zmenu politického, štátneho či hospodárskeho života. ${ }^{107}$ Ich zmyslom bolo vytvorit’ z trestného zákona nástroj, ktorý by, i napriek pečati doby, v ktorej vznikol, mohol plnit’ úlohu ochrany novo-vznikajúcej spoločnosti, až pokým sa v právnej forme konštituujú nové spoločenské hodnoty. ${ }^{108}$ Príprava takto rozsiahlej novely preto musela ústit' do precízneho nastavenia intertemporálnych ustanovení. Jedným z nich bol aj článok II ods. 3 novely $1990^{109}$ a článok II ods. 4 novely $1990 .{ }^{110}$

Tieto ustanovenia boli predmetom skúmania Najvyšším súdom ČR. Napríklad ${ }^{111}$ v judikáte R 25/1991 tr. Najvyšší súd ČR zdôraznil, že článok II ods. 3 novely 1990 (o tom, že tresty uložené pred účinnost'ou tohto zákona za činy, ktoré nad’alej nie sú trestnými činmi, sa nevykonajú) sa týka iba trestu odňatia slobody, a nie iných druhov trestov. Uvedené podl'a tohto súdu vyplýva tiež zo zámeru zákonodarcu, a teda zo zásady, že by bolo neprimerané, aby po 1. 7.1990 boli vykonávané právoplatne uložené tresty odňatia slobody za trestné činy, ktoré budú posudzované už iba ako priestupky. Pokial' by však išlo o trest zákazu činnosti, peňažný či iný trest, nie je účelné upúšt’at' od výkonu týchto trestov, ked’že také alebo obdobné „,tresty“", môžu byt' uložené aj za priestupky. ${ }^{112}$ Skokový nárast súm určujúcich jednotlivé hranice výšok škôd predstavuje aj radikálnu zmenu kritérií na vyvodzovanie trestnej zodpovednosti či určenie právnej kvalifikácie. Záleží však najmä od vôle zákonodarcu, pokial už bolo právoplatne rozhodnuté o vine

106 Rozsiahlou novelou v roku 1990 sa vypustila značná čast’ skutkových podstát poskytujúcich ochranu socialistickému zriadeniu, napr. celý tretí oddiel druhej hlavy ( $\int 132$ rozkrádanie majetku v socialistickom vlastníctve, \133 Neoprávnené užívanie veci z majetku v socialistickom vlastníctve, a mnoho d’alších). $\mathrm{V}$ neposlednom rade sa trest smrti nahradil výnimočným trestom. Uložený trest smrti sa pritom zmenil na trest odňatia slobody na doživotie.

107 BALÁŽ, P. Trestné právo bmotné: V šeobecná a osobitná čast'. 1. vyd. Bratislava: IURA EDITION, 2001, s. 208.

108 TERYNGEL, J. K novele trestního zákona. In: Právo a qákonnost. Praha: Ministerstvo spravedlnosti ČR, 1990, č. 9, s. 515-524.

109 Čl. II ods. 3 novely 1990: „Trest odňatia slobody uložený pred účinnost'ou tohto zákona za čin, ktorý nie je trestným činom, prípadne jeho nevykonaný zvyšok, sa nevykoná. Ustanovenie o súbrnnom treste sa v takom prípade nepouřije. Ak za taký trestný čin alebo prečin a zbiehajúci sa iný čin bol uložený úbrnný alebo súbrnný trest, súd trest pomerne skeáti; pritom pribliadne na vájomný pomer qávažnosti činov, ketoré od úcinnosti tobto zákona nie sú trestnými činmi, a ostatných činov."

110 Čl. II ods. 4 novely 1990: „Trest odñatia slobody uložený pred účinnostou tobto zákona za čin, ktorý sa bude nad’alej posudzovat' ako miernejšie trestný, súd pomerne skéáti; pritom pribliadne na vájomný pomer trestnej sadzby ustanovenej na pôvodný trestný čin alebo prečin a sadz̧by ustanovenej na miernejšie trestný čin. Podla rovnakých zásad postupuje, ak za taký čin a zbiebajúci sa iný čin bol uložený úhrnný alebo súbrnný trest."

111 Judikatúra je však širšia, pozri tiež R 9/1992, resp. Rč 7/1993.

112 Pozri tiež R 9/1992 tr. alebo R 7/1993 tr. Posledný z uvedených judikátov napríklad zdôrazňuje, že ak bol uložený podmienečný trest odňatia slobody pred účinnost'ou novely 1990 za čin, ktorý už nie je trestným činom, nemožno vzhl’adom na čl. II ods. 3 novely 1990 rozhodnút', že sa tento trest vykoná, a to bez ohl'adu na skutočnost', ktorá by inak odôvodňovala záver, že sa obvinený v skúšobnej dobe neosvedčil. 
a treste, či sa rozhodne pre doplnenie ustanovenia, podl’a ktorého sa tresty uložené za činy spáchané pred účinnost’ou novej právnej úpravy nevykonajú, prípadne pomerne skrátia. ${ }^{113}$ Vzhl'adom na takmer dve dekády trvajúce nereagovanie na zmeny ekonomickej reality sa však záverom prihovárame k prehodnoteniu (ne)existencie prechodného ustanovenia v normatívnom texte, a to pod vzorom článku II ods. 3 a ods. 4 novely 1990.

\section{Záver}

Súčasné trestné právo - na rozdiel napr. od prísnosti a krutých praktík podl'a starovekého trestného práva ${ }^{114}$ - je charakterizované humanizmom a kriminalizáciou len v nevyhnutných prípadoch. Týmto atribútom zodpovedajú aj dekriminalizačné snahy pri bagatel'ných deliktoch, čomu z časti zodpovedá aj Novela (TZ ČR prijatá v roku 2020). $\mathrm{Na}$ druhej strane však v tomto prípade nie je možné hovorit' o pravej forme dekriminalizácie, len o zosúladení stavu s ekonomickou situáciou. Zámer reagovat' zvyšovaním hraníc jednotlivých typov škôd na vývoj inflácie bol pritom podla dôvodovej správy k zákonu č. 265/2001 Sb. vyjadrený aj samým českým zákonodarcom.

Za rešpektovania inflačného vývoja, komparatívnych záverov, ako i celkového rozsahu trestnej činnosti s dôrazom na výpočet priemernej výšky škody spôsobenej hospodárskou či majetkovou kriminalitou bola predmetná Novela vyhodnotená ako akceptovatel'ná s rozdielom vo finančnom obsahu škody nikoli nepatrnej. Tá má podl’a Novely predstavovat' sumu 10000 Kč. V súlade so závermi, ktoré v roku 1979 prezentoval nemecký Bundesverfassungsgericht, konštatujeme, že zákonodarca má široký priestor na uváženie, ako bude reagovat' na bagatel'nú kriminalitu, pričom jeho reakcia musí byt' adekvátna, a vždy výsledkom detailného uváženia. Ústavné súdnictvo totiž v otázkach kriminalizácie nemá suplovat' jedinečnú úlohu zákonodarcu (adekvátne tiež Ústavní soud ČR v náleze sp. zn. Pl. ÚS 46/18). Vzhl’adom na inflačný vývoj by bolo vhodnejšie navýšenie hranice škody nikoli nepatrnej na najviac $7500 \mathrm{Kč}$, čo by bola na účely trestného zákonodarstva úroveň dostačujúca, avšak český zákonodarca sa v rámci svojej vol’nej úvahy v roku 2020 rozhodol pre navýšenie až na 10000 Kč. Zvyšovanie hranice nad nevyhnutnú mieru môže spôsobit' negatívne efekty (zat'aženie orgánov prejednávajúcich priestupky, nižšia ochrana poškodených), resp. môže byt' hodnotené ako „opačný extrém“v porovnaní s rozsiahlou kriminalizáciou bagatel’ných deliktov v rakúskom a nemeckom trestnom práve ${ }^{115}$, ktorá je zmiernená výlučne privilegovanou kvalifikáciou, resp. návrhovým mechanizmom.

113 Pozri tiež Rč $17 / 2007$.

114 Pozri GREGOR, M. „Desivé“ tresty v rímskom práve elektronický dokument. Comenius [online]. 2018, roč. 3, s. 1-3 [cit. 9. 5. 2020]. Dostupné na: https://comenius.flaw.uniba.sk/index.php/kategorie/ pravne-dejiny-filozofia/47-desive-tresty-v-rimskom-prave

115 Úplná dekriminalizácia, resp. presun bagatel’ných deliktov z trestného práva do priestupkového práva sú podl’a Kaisera v podmienkach nemeckého právneho poriadku neakceptovatel'né. KAISER, G. Möglichkeiten der Bekämpfung von Bagatellkriminalität in der Bundesrepublik Deutschland. Zeitschrift für die gesamte Strafrechtswissenschaft, 1978, roč. 90, č. 4, s. 877-904. 
Obohacujúcim námetom pre českú právnu úpravu môže byt' do budúcna doplnenie pojmu „postihnutý“ do vybraných skutkových podstát trestných činov, najmä ako znaku základnej skutkovej podstaty trestného činu krádeže. Jeho zavedením by český zákonodarca efektívne chránil spoločnost' pred prípadmi, ked' by mohlo dochádzat' k opakovanému prisvojeniu si cudzej veci tým istým páchatel’om. Generálno-preventívny účinok tak zostane zachovaný i napriek navýšeniu hranice medzi trestnou a administratívnou zodpovednost'ou. Na zváženie bolo dané aj častejšie využitie tohto pojmu v TZ ČR.

Ďalší ciel' našej štúdie pozostával zo zistenia, či je prinavrátenie nadviazania škody na jeden $z$ flexibilných inštitútov možné aj ${ }^{116} \mathrm{v}$ našich podmienkach. Výsledkom je, že suma životného minima môže byt' na účely TZ SR vhodným inštitútom, ktorý by rešpektoval ako právne, tak aj ekonomické požiadavky. V tejto časti sa tiež naplno prejavila naša preferencia naviazania na činitel’ inflácie (nie minimálnej alebo priemernej mzdy), ked’že kritériá podmienok trestnej zodpovednosti sa pod jej vplyvom naozaj zužujú pomalšie, čím sa z roka na rok predchádza skokovému nárastu súm určujúcich zákonnú kategorizáciu škôd. Z dôvodov bližšie špecifikovaných v piatej kapitole štúdie by však suma životného minima $\mathrm{v}$ českom trestnom zákonodarstve neobstála.

Záverom bolo potrebné apelovat' na potrebu intertemporálneho ustanovenia, podl'a ktorého sa tresty uložené za činy spáchané pred účinnost'ou novej právnej úpravy nevykonajú, prípadne pomerne skrátia. Ako už bolo niekol'kokrát uvedené, skokový nárast súm určujúcich zákonnú kategorizáciu škôd znamená aj radikálnu zmenu kritérií na vyvodzovanie trestnej zodpovednosti či určenie právnej kvalifikácie. Dúfame preto, že ani tento námet nezostane nepovšimnutý.

116 Naviazanie jednotlivých typov škôd na minimálnu mesačnú mzdu využíva v určitom rozsahu Pol'sko. $\mathrm{Na}$ mesačnú nezdanitel'nú čast' základu dane na daňovníka (ktorá je bezvýhradne spojená so sumou životného minima) zasa nadväzuje Ukrajina. 